\title{
Kendine Aşırı Güven ve Ölçme Yöntemleri: Davranışsal Finans Kapsamında Bir Literatür İncelemesi*
}

\section{Overconfidence and Measurement Methods: A Literature Review in the Context of Behavioral Finance}

\author{
Bilgehan Tekin ${ }^{\mathrm{a}, * *}$ \\ ${ }^{a}$ Dr. Öğr. Üyesi, Çankırı Karatekin Üniversitesi, İ.İ.B.F. Fakültesi, İşletme Bölümü, 18100, Çankırı/Türkiye. \\ ORCID: 0000-0002-4926-3317
}

\section{MAKALE BİLGİSI \\ Makale Geçmişi: \\ Başvuru tarihi: 05 Ocak 2018 \\ Düzeltme tarihi: 07 Ocak 2018 \\ Kabul tarihi: 19 Şubat 2018}

\section{Anahtar Kelimeler:}

Kendine Așırı Güven

Davranışsal Finans

Psikolojik Önyargılar

Önyargıların Ölçülmesi

\section{ARTICLE INFO}

\section{Article history:}

Received 05 January 2018

Received in revised form 07 February 2018

Accepted 19 February 2018

\section{Keywords:}

Overconfidence

Behavioral Finance

Psychological Biases

Measurement of Biases
ÖZ

Bu çalışmada, davranışsal finans ve psikoloji literatürlerinde yer alan çalışmalara oldukça sık konu olmuş kendine aşırı güven davranışsal önyargısı ve bu önyargının ölçülme veya açığa çıkarılma yöntemleri incelenmiştir. Kendine aşırı güven, bireylerin kendi yetenek ve bilgi düzeylerine gerçekçi olmayan bir şekilde aşırı güvenmeleri olarak ifade edilebilir. Kendine aşırı güvenin ölçülmesi bağlamında literatürde yer alan çalışmalar incelendiğinde birbirinden oldukça farklı yöntemlerin kullanıldığı görülmektedir. $\mathrm{Bu}$ yöntemlerden özellikle yatırımcıların kendine aşırı güvenleri ölçülmek istendiği durumlarda ve diğer psikolojik araştırmalarda kalibrasyon skoruna dayalı güven aralıklı anket yönteminin ve davranışsal kurumsal finans kapsamında yönetsel önyargının ölçülmesi gerektiği durumlarda ise ilk defa Malmendier ve Tate tarafindan kullanılan opsiyon kullanımı temelli yaklaşımın tercih edildiği görülmektedir. Çalışma sonucunda kendine aşırı güvenin ölçümünde kullanılacak ölçek konusunda henüz tam bir fikir birliğinin olmadığı görülmüştür.

\section{A B S T R A C T}

In this study, overconfidence behavioral bias, which is frequently mentioned in the behavioral finance and psychology literatures, and measurement methods of this bias are examined. Overconfidence can be expressed as an unrealistic trust of individuals in their ability and knowledge. When the studies in terms of measuring overconfidence in the literature are examined, it is seen that quite different methods are used. These methods, especially when the overconfidence of investors is to be measured, and in other psychological studies, it is seen that the use of the confidence-interval survey method based on the calibration score is preferred. And when the managerial bias is to be measured within the scope of behavioral corporate finance it is seen that the use of the option usebased approach which is used by Malmendier and Tate for the first time is preferred. As a result of the study, it has been observed that there is no complete consensus on the scale to be used for the measurement of overconfidence.

\section{Giriș}

Geleneksel ekonomik modeller, insan davranışlarını gerçekçi olmayan üç özellik bağlamında açıklamaya çalışmaktadır. Bu özellikler ekonomik insanı (homo economicus) betimleyen rasyonellik, irade ve bencilliktir. 2017 yılında Nobel Ekonomi Ödülü' nü kazanan Richard Thaler bir başka araştırmacı Mullainathan ile 2000 yılında yaptıkları çalışmada geleneksel ekonominin bu varsayımlarını sınırlı rasyonellik, sınırlı irade ve sınırlı bencillik şeklinde ele alarak davranışsal finans bağlamında yeniden tanımlamışlardır (Mullainathan ve Thaler, 2000).

Günümüzde geleneksel finansın ve modellerinin ekonomilerde ortaya çıkan problemlerin çözümünde yeterli olamadığı yaşanan krizlerle de açık bir şekilde görülmektedir. Kriz dönemlerinde (uzun ve kısa vadeli veya çok kısa vadeli) piyasalarda yaşanan olağanüstü

\footnotetext{
* Bu çalışma, 2015 yılında Sakarya Üniversitesi Sosyal Bilimler Enstitüsü tarafından kabul edilen "Firmaların Finansal Kararlarında Davranışsal Önyargıların Etkisi” başlıklı Doktora tezinden türetilmiş ve 19-21 Ekim 2017 tarihlerinde İstanbul'da düzenlenen 3. Uluslararası Afro-Avrasya Araştırmaları Kongresi'nde bildiri olarak sunulmuştur.

** Sorumlu yazar/Corresponding author.

e-posta: btekin@karatekin.edu.tr
} 
dalgalanmalar geleneksel modellerin yetersizliğini ortaya koymaktadır. Aynı şekilde yatırımcılar açısından bakıldığında yatırım kararlarının sadece matematiksel ve istatistiksel yöntemlerle ilişkilendirilerek verildiğini düşünmek fazla rasyonel bir yaklaşım olacaktır.

Yatırımcı boyutunda olduğu gibi kurumsal finansal kararlarda da yöneticilerin aldıkları kararların tam rasyonel kararlar olamayacağı açıktır. Çünkü insanların büyük bir çoğunluğu psikolojik, duygusal ve davranışsal faktörlerin etkisi altında kalarak karar alırlar. Bu noktada geleneksel finansın eksik kalan insan psikolojisi ve davranışı boyutunu ele alan davranışsal finans ve savları gündeme gelmektedir.

Davranışsal finans, disiplinler arası bir çalışma alanıdır ve bu çalışma alanı psikoloji, sosyoloji, davranış bilimleri, ekonomi ve finans gibi farklı disiplinleri bir araya getirir. Kaynağı ise beklenen fayda teorisi ve karar teorisidir. Davranışsal finans temel olarak belirsizlik altında alınan kararlarda meydana gelen psikolojik yanılsamaların incelenmesini konu alır. Davranışsal finans, piyasalarda işlem yapan yatırımcıların bir takım inançlar ve kişisel tercihler nedeniyle tamimiyle rasyonel olmadiklarını ve etkin piyasalar hipotezinin her durumda geçerli bir hipotez olamayacağını öne sürmektedir. Davranışsal finans, psikoloji ve sosyoloji gibi bilim dallarında yapılan çalışmalar sonucu insan psikolojisine yönelik olarak ortaya konulmuş önyargılar ve hevristikler gibi psikolojik faktörlerin, ekonomi ve finansal piyasalarda gerçekleştirilen çeşitli finansal işlemler üzerindeki etkisinin araştırılmasını konu almaktadır. Söz konusu işlemler ise çıktıları belirsiz olan finansal kararlarla ilgilidir (Tekin, 2015).

Davranışsal finans literatüründe üzerinde en çok durulan davranışsal önyargı ise kendine aşırı güven önyargısıdır. DeBondt ve Thaler (1995) tarafından da belirtildiği gibi insanların kendine aşırı güven önyargısına sahip olmaları psikoloji alanının en sağlam bulgularından biridir. Kendine aşırı güven, psikoloji literatüründe, kişilerin kendi yetenek ve bilgilerine olan gereğinden fazla güvenlerini ifade etmektedir (Odean, 1998). Kendine aşırı güven, bir kişinin sahip olduğu yeteneklerini, başarı beklentilerini, olayların pozitif çıktılarını ya da sahip olduğu bilginin doğruluğunu abartması eğilimi ve kişilerin sahip oldukları bilgilerinin sınırlarını bilmemeleri sonucu ortaya çıkmaktadır (Conger ve Wolstein, 2004). Bireyler genel olarak kendine aşırı güvenen canlılardır. Hayatın her anında karar verme aşaması ile karşı karşıya kalan insanların büyük çoğunluğu verecekleri kararlarda kendi bilgi ve yeteneklerine güvenme eğilimdedirler. Psikoloji ve davranışsal finans alanlarında yapılan çalışmalar da bunu destekler niteliktedir (Lichtenstein, Fischhcoff ve Phillips, 1982; Camerer ve Lovallo, 1999).

$\mathrm{Bu}$ çalışma, modern davranışsal finansın en fenomen ve en anlamlı kavramlardan biri olan kendine aşırı güvene ilişkin literatürü dikkate alarak hazırlanmıştır. Çalışmada ilgili literatürden yola çıkılarak, kendine aşırı güven davranışsal önyargısına, çeşitli çalışmalarda yararlanılan ölçme yöntemlerine ve finansal kararlarla olan ilişkisine yer verilecektir. Burada amaç uluslararası alanda sıklıkla yer verilen söz konusu önyargıya ve finansal kararlar üzerindeki etkisine dikkat çekmektir. Çalışma sonucunda gelecekte yapılacak çalışmalarda yararlanılabilecek bir kaynak ortaya konulması bir başka amaçtır. $\mathrm{Bu}$ çalışmanın hazrılanmasında, 2015 yılında bu çalışmanın yazarı tarafindan hazırlanan "Firmaların Finansal Kararları Üzerinde Davranışsal Önyargıların Etkisi” başlıklı doktora tezinden yararlanılmıştır.

\section{Davranışsal Finans Alanında Kendine Aşırı Güven Kavramı}

Kendine aşırı güven (overconfidence) terimi psikoloji literatüründe ilk defa 1960'lı yıllarda duyulmaya başlanmış ve sonrasında akademik çalışmalara oldukça geniş bir şekilde konu olmuştur. İlk olarak Oskamp (1965) tarafindan tanımlanan kendine aşırı güven önyargısının, hayatın çeşitli karar alanlarında süreçlere etki ettiği önemli araştırmacılar tarafından da belirtilmiştir (Lichtenstein ve Fischoff, 1977; Alpert ve Raiffa, 1982; Bazerman, 1990).

Kendine aşırı güven, oldukça iyi bir şekilde tasarlanmış psikolojik teori olarak da ifade edilir. Ana hatları ise; eksik kalibrasyon, ortalamadan daha iyi etkisi, kontrol yanılsaması ve gerçekçi olmayan iyimserlik kavramlarından oluşur (Skala, 2008). Psikoloji literatüründe kendine aşırı güvenin, kişilerin kendi yetenek ve bilgilerine olan gereğinden fazla güvenlerini ifade ettiği belirtilmektedir (Odean, 1998:1888). Kendine aşırı güven, bir kişinin sahip olduğu yeteneklerini, başarı beklentilerini, olayların pozitif çıktılarını ya da sahip olduğu bilginin doğruluğunu abartma eğilimi ve kişilerin sahip oldukları bilgilerinin sınırlarını bilmemeleri sonucu ortaya çıkmaktadır (Conger ve Wolstein, 2004).

Bir başka görüşe göre kendine aşırı güven önyargısı, karar vericilerin, ilk değerlendirme aşamalarında aşırı iyimser olmaları sonucu ortaya çıkmaktadır. Bu durum, bireylerin daha sonra olayın içerisine edindikleri ek bilgileri dahil etmelerini zorlaştırır çünkü kendine aşırı güvenleri buna izin vermez (Fischoff vd., 1977; Alpert ve Raiffa, 1982).

Bazerman (1994) ise kendine aşırı güveni, insanların orta düzeyden zor düzeye kadar ki zorluk seviyesine sahip sorulara cevap verirken ilk tahminlerinin doğruluğunu abartma eğilimine işaret eden karar verme yanlılığ 1 şeklinde tanımlamaktadır. Schaefer vd. (2004) ise insanların kendi tahminlerinin doğruluk düzeylerini abarttıkları bir yargısal hata olarak tanımlarken aynı zamanda doğruluk ve güven arasındaki olumlu fark olduğunu belirtmektedirler.

Kendine aşırı güvenin diğer psikolojik faktörlerle ilişkisi de söz konusudur. Örneğin narsist insanların diğerlerine göre daha yüksek düzeyde kendine aşırı güvene sahip olduğu görülmüştür. Bu durum bu türden kişilerin verdikleri kararlar sonucu ortaya çıkan kayıplarının da daha fazla olmasına neden olmaktadır (Campbell ve Goodie, 2004).

Diğer yandan kişilerin kendi yargısına güven duygusu ve bilişsel doğruluk ile kendine aşırı güven arasındaki potansiyel ilişkide yer alan sinirsel süreçlerin daha iyi anlaşılmasının sağlanması da ayrıca önemlidir (Molenberghs vd., 2016). Molenberghs vd. (2016), bir sosyal ve bilişsel akıl yürütme araştırmasında, beyin taraması (MR) ile 308 gönüllü deneğin kendi performanslarını değerlendirdikleri bir çalışma yapılmıştır. Deneklere bir kişinin hikayesini anlatan bir videoyu izlettirildikten sonra onlardan kişinin ne söylediği konusunda zor bir soruyu cevaplamaları istenmiştir. Daha sonra deneklerden verdikleri cevaplara duydukları güveni belirtmeleri istenmiş ve denekler cevaplarının doğru olduğunu hissettiklerini belirtmişlerdir. Ardından araştırmacılar, deneklerin kendilerinin doğru 
cevap verme konusundaki performanslarını değerlendirmede ne kadar iyi olduklarını ölçmüştür. $\mathrm{Bu}$ sürece metabiliș (metacognition) denmektedir. Metabilişin önemli bir özelliği kişinin performansını doğru bir şekilde ölçebilmesidir. İnsanlar metabilişsel becerilerinde büyük farklılıklar gösterir ve genel olarak performanslarını değerlendirirken kendinden eminlerdir. Bu durum, büyük kayıplarla sonuçlanacak zayıf kararlar verilmesine neden olur. Metabiliş, kişinin kendi bilișsel süreçlerini düşünme ve izleme becerisi şeklinde tanımlanmaktadır (Dunlosky and Metcalfe, 2009). Bu bağlamda, çalışmanın sonucunda, kendine güvenin, metabilişsel doğruluk ile pozitif ilişkili olduğu görülmüştür. Bununla birlikte, bu ilișkinin, deneklerin gerçek doğruluk seviyeleriyle negatif olduğu belirlenmiştir. $\mathrm{Bu}$ durum deneğin metabilişsel yargısının doğruluğunu zayıflatabilecek bir ön yargı olduğunu göstermiştir.

\subsection{Finansal Kararlarda Kendine Așırı Güven}

Finansal piyasaların işleyişi ve yatırımcıların davranışları bağlamındaki kendine aşırı güven varsayımı, yatırımcıların kendi yetenek, bilgi ve tecrübelerine olan aşırı güvenleridir (Michailova, 2010). Kendine aşırı güven esas olarak psikoloji araştırmaları sonucu ortaya çıkmış ve finans alanında cevap bulunamayan bazı sorulara yanıt olabileceği düşünülerek finans alanında da dikkate alınmaya başlanmıştır. Örneğin piyasalarda gözlemlenen anomaliler ve olağandışı dalgalanmalar ve genel finansal modellerin eksik yönleri kendine aşırı güven önyargısı v.b. psikolojik ve davranışsal faktörler dikkate alındığında daha anlamlı hale gebilmektedir.

Finans literatürü açısından bakıldığında kendine aşırı güven, çoğunlukla finansal piyasalarda işlem gerçekleştiren yatırımcı davranışları üzerine incelenmiştir. Kendine aşırı güven önyargısının kaynağı bireylerin kendi yeteneklerine, bilgilerine ve riski önemsememeye olan aşırı güvenleridir. Kyle ve Wang (1997) çalışmalarında kendine aşırı güvenen yatırımcıların rasyonel yatırımcılardan daha yüksek beklenen getiriye sahip olacaklarını ve daha fazla fayda elde edebileceklerini belirtmektedirler. Sebebi ise kendine aşırı güvenin agresif yatırıma neden olmasıdır (Baker ve Nofsinger, 2010:250). Bununla birlikte, zaman içerisinde piyasalar bu açığı kapatacaklarından, kendine aşırı güven önyargısının sağladığı bu avantaj, ilk harekete geçen kendine aşırı güven önyargısına sahip yatırımcılar için geçerli olacaktır. Piyasa işlem hacmi, kendine aşırı güvene sahip yatırımcıların olduğu durumda oldukça yüksek düzeylerde gerçekleşecektir (Lai, 2011).

Finansal piyasalar ve finansal piyasalarda yer alan aktörlerin irrasyonel finansal kararlarına yönelik olarak yapılan çalışmaların sayısı her geçen gün artmaktadır. Bu çalışmalarda dikkat çeken bir başka husus çoğunlukla kendine aşırı güven davranışsal önyargısı üzerine odaklanmalarıdır (Kyle ve Wang, 1997; Benos, 1998; Odean, 1998; Wang, 1998, 2001; Daniel vd., 1998, 2001; Caballe ve Sakaovics, 2003; Palomino ve Sadrieh; 2011).

Örneğin Kyle ve Wang (1997), Wang (2001), , Shefrin (2002), Peng ve Xiong (2006), Statman, Thorley ve Vorkink (2006), Baker ve Nofsinger (2010), Burnside, Han, Hirshleifer ve Wang (2011) gibi araştırmacılar bireysel yatırımcıların finansal kararları üzerine odaklanmışlardır. $\mathrm{Bu}$ çalışmalar genel olarak piyasalarda özellikle hisse senedi piyasalarında yatırımcıların gerçekleștirdikleri işlemler üzerinde kendine aşırı güvenin etkisini konu almaktadır. Bu çalışmaların ulaştıkları ortak sonuç ise kendine aşırı güvenen yatırımcıların gerçekleştirdiği işlem hacimlerinin yüksek olduğu ve bu durumun zarar etmelerine neden olduğu yönündedir.

Kendine aşırı güven önyargısının aynı zamanda yatırımcıların genel olarak riskli pozisyon alarak, rasyonel yatırımcılara göre daha büyük işlem hacimlerinde ve miktarlarda alım-satım yapmalarına neden olduğu ifade edilir. Ayrıca kendine aşırı güven önyargısı piyasalarda, olağanüstü işlem hacimlerine (De Bondt ve Thaler, 1985; Shiller, 2000; Caballe ve Sakovics, 2003, Glaser ve Weber, 2007; Trinugroho ve Sembel, 2011) ve aşırı fiyat volatilitesine neden olmaktadır (Scheinkman ve Xiong, 2003; Benos, 1998; Daniel vd., 1998). Odean (1998) eksik rekabet piyasalarında, kendine aşırı güven önyargısının piyasa bozulmalarına neden olabildiğini ve piyasa dengesinin mevcut olduğu koşullarda, beklenen hacim, piyasa derinliği, fiyat volatilitesi ve etkin bilgi düzeyinin içerden bilgi sağlayan kişilerin kendine aşırı güven önyargılarının etkisi ile birlikte artacağını ifade etmektedir.

Kendine aşırı güvenin yönetici davranışları üzerine etkisi de incelenmiştir. Bu konuda yapılan çalışmalardan ilkinin Roll (1986) tarafından yapıldığı kabul edilir. Roll bu çalışmasında, kendine aşırı güvenin birleşme kararları üzerindeki etkisini incelemiş ve "Kibir Hipotezi" ni ileri sürmüştür. Buna göre, kurumsal devralmalar sırasında, bireysel karar vericilerin kendilerine olan aşırı güvenleri, devralınacak şirket için gereğinden fazla fiyat biçmelerine ve ödeme yapmalarına neden olabilmektedir (Tekin, 2015). Gervais, Heaton ve Odean (2002, 2003), Ying, Xing ve Chao-nan (2005), Camerer ve Lovallo (1999), Barber ve Odean (2001), Malmendier ve Tate (2005, 2008, 2011) gibi araştırmacılar kendine aşırı güveni firma boyutunda ele almış ve yöneticilerin finansal kararları üzerindeki etkisini incelemişlerdir. Diğer bazı çalışmalar ise şöyledir: Barros ve Silveria (2007), Ben-David vd. (2013), Cronqvist vd. (2012), Fairchild (2010), Hackbarth (2002), Malmendier vd. (2011), Shao ve Wang (2013), Gervais vd. (2011), Hirshleifer vd. (2012), Chen, Crossland ve Luo (2015), Adam, Fernando ve Golubeva (2015), Ataullah, Vivian ve Xu (2017), Jeong-Ho ve Daecheon (2018).

Bu çalışmalar sonucunda kendine aşırı güvenen yöneticilerin sermaye yapısında yüksek düzeyde dış borçlanmaya yer verdikleri, kendi yeteneklerini, yaptıkları yatırımlardan bekledikleri nakit akışlarını ve işletme faaliyetlerinin olası sonuçlarını abarttıkları, devralma ve birleşme yatırımlarında hatalı kararlar verdikleri gibi sonuçlar ortaya konulmuştur.

\subsection{Türkiye' de Kendine Aşırı Güveni Konu Alan Çalışmalar}

Türkiye' de yapılan çalışmalara bakıldığında ise ilk çalışmalardan birinin Korkmaz ve Çelik (2007) tarafindan yapıldığı görülmektedir. Araştırmacılar çalışmalarında aşırı güven olgusunu İMKB'de işlem yapan yatırımcıların davranışları üzerinde incelenmiştir. Çalışmanın sonuçlarına göre, kendine aşırı güvenen yatırımcıların pazar kazancından sonra daha fazla işlem yaptıklarına ve kazandıran pazarda daha aktif olduklarına dair kanıtlar elde edilmiştir. Diğer taraftan, kendilerine aşırı güvenen yatırımcıların pazar 
kazancı sağladıktan sonra riskli varlıklara daha fazla işlem yaptıkları konusunda ise yeterli kanıt elde edilememiştir.

Kahyaoğlu (2012), farklı demografik ve sosyo-ekonomik özellikteki yatırımcıların işlem hacmi, işlem sıklığı ve portföy çeşitlendirme seviyeleri açışından farklılaşmalarını incelediği çalışmasında cinsiyet, medeni durum ve aylık gelir durumu gibi farklı sosyo- ekonomik ve demografik özellikteki yatırımcılara göre işlem hacmi, işlem sıklığı ve portföy çeşitlendirme seviyelerinin anlamlı olarak farklılık gösterdiğini tespit etmiştir.

Tomak (2013), Türk imalat işletmelerinde aşırı güven ile sermaye yapısı arasındaki ilişkiyi araştırmıştır. Yönetici güvenine ek olarak, temel faktörlerin piyasa kaldıraç oranları üzerindeki etkisini analiz etmiştir. Çalışma sonucunda, güven ve kaldıraç arasındaki ilişkinin belirsiz olduğunu tespit etmiştir. Kendine aşırı güvenen yöneticilerin daha fazla dış borç kullanma eğilimi gösterdiğine ilişkin iddiayı doğrulayacak yeterli kanıt ise bulamamıştır.

Şahin ve Yılmaz (2014) İngiltere'deki kişilerin aşırı güven yanlılıklarını araştırmışlardır. Çalışmalarının sonuçları, insanların genellikle aşırı güven duygusuna sahip olduğunu göstermiştir. Araştırmaya katılan deneklerin çoğu kendilerini ortalamanın üstünde ve aşırı düzeyde yüksek bilgiye sahip olduklarını düşünmektedirler. Buna ek olarak, katılımcıların çoğunluğu hisse senedi yatırımında ortalamadan üstün olduklarını düşünmektedirler.

Tekin (2016) firmalarda karar vericilerin finansman kaynağı tercihlerinde kendine aşırı güven ve kayıptan kaçınma davranışsal önyargıların etkisini incelemiştir. Çalışma sonucunda firmalarda finansman kararlarında $\mathrm{n}$ sorumlu kişilerin kendine aşırı güvenli ve kayıptan kaçınan bireyler oldukları görülmüştür. KOBİ sahiplerinin veya yöneticilerinin verdikleri finansman veya sermaye yapısı kararları davranışsal önyargı düzeylerine göre farklılık gösterebildikleri sonucuna ulaşmıştır.

Küçüksille, Özmutaf ve Mizrahi (2016) İzmir'de yaşayan ve hisse senedi piyasalarında yatırım yapan bireysel hisse senedi yatırımcılarının sosyo - demografik faktörler bağlamında aşırı güven düzeyi algılarını araştırmışlardır. Araştırma sonucunda "Bireysel hisse senedi yatırımında aşırı güven düzeyi algısının” yaş, medeni durum, eğitim durumu ve meslek türüne göre farklılık gösterdiği ancak farklılıkların güven düzeyi düşüklüğünde yoğunlaştığı belirlemişlerdir. Ayrıca bireysel hisse senedi yatırımcılarının kendine aşırı güven düzeylerinin cinsiyete göre farklılık göstermediğini tespit etmişlerdir.

\section{Kendine Aşırı Güvenin Bileşenleri}

Literatürde kendine aşırı güven davranışsal önyargısının konu edildiği çalışmalara bakıldığında, kendine aşırı güveni meydana getiren, daha iyi anlaşılmasına ve daha etkin ölçülmesine imkan tanıyan bazı kavramlardan söz edildiği görülmektedir. Söz konusu kavramlar eksik kalibrasyon (miscalibration (Alpert ve Raiffa, 1982), ortalamadan daha iyi etkisi (better than average effect (Svenson, 1981)), kontrol yanılsaması (Langer, 1975) ve iyimserlik (Weinstein, 1980) ya da gerçekçi olmayan (aşırı) iyimserlik (Weinstein, 1982)' dir. Bu kavramlar aynı zamanda 'pozitif yanılsamalar "şeklinde de ifade edilmektedir (Taylor ve Brown, 1988).

\subsection{Kalibrasyon ve Eksik Kalibrasyon}

Kalibrasyon ve eksik kalibrasyon kavramlarına ilk defa Lichtenstein, Fischoff ve Philips (1977) tarafindan yapılan çalışmada değinilmiştir. Araştırmacılar güven derecelerinin geçerliliğini doğrulamanın bir yolunun bu tür güven ifadelerinin kalibrasyonuna bakmak olduğunu belirtmişlerdir. Buna göre uzun vadede, belirli bir olasılık tahsis edilmiş tüm önermeler için, doğru cevap oranı, atanmış olasılığa eşitse, bir kişi iyi kalibre edilmiş demektir (Tekin, 2015).

Eksik kalibrasyon, kendine aşırı güven ile aynı tanıma sahiptir (Skala, 2008). Kendine aşırı güvenin ölçümünde kalibrasyonun kullanıldığı çalışmalarda (Glaser ve Weber, 2007), katılımc1lar bir dizi genel bilgi sorusuna cevap verirler ve verdikleri her cevabın doğru olduğuna olan inançlarını belirtmeleri istenir. Kalibrasyon, doğru cevap verilen soruların yüzdesi ile katılımcıların verdikleri cevaplara duydukları güvenin ortalamalarının karşılaştırılması ile test edilir. Bu karşılaştırma sonucunda \%P güven düzeyinde verilmiş cevapların yaklaşık doğruluk oranı \%P olmalıdır. Eğer böyle bir durum ölçülmemişse cevaplayıcının eksik kalibre olduğu söylenir.

\subsection{Ortalamadan Daha İyi Etkisi}

K. Patricia Cross, 1977 yılında yaptığı çalışmada öğretim üyelerinin \%50' sinden daha azının kendilerini ortalamanın üstünde eğitmen olarak değerlendirecekleri beklentisine rağmen \%94' ünün kendilerini ortalamanın üzerinde değerlendirdiklerini tespit etmiştir. Svenson (1981), kişinin kendisini yetenekli gördüğü herhangi bir konuda ve her koşulda ortalama bir bireyden daha iyi olduğuna inanmasının kendine aşırı güvenin kaynağı olduğunu belirtmiştir. Benzer şekilde, Taylor ve Brown (1988), insanların kendileriyle ilgili olarak gerçekçi olmaktan uzak bir takım pozitif inançlara sahip olduklarını (örneğin kendilerinin, ortalama bir insandan daha iyi yeteneklere sahip olduklarına olan inançları) ifade etmektedir. Kişilerin sergiledikleri bu davranışa "better than average (ortalamadan daha iyi etkisi)" adı verilmiştir. Svenson'un (1981) bu konuda yaptığı çalışmada, \%30' luk araç kullanabilen öğrenci popülasyonunun \%82'sinin, kendilerinin en güvenli sürücü olduklarını iddia ettiklerini belirtmiştir.

\subsection{Kontrol Yan1lsamas1}

Kontrol yanılsaması ise bireylerin olayların sonuçlarına müdahale edebileceklerine ve onların, istedikleri takdirde, farklı şekillenmelerini sağlayabileceklerine olan inançlarını ifade etmektedir. Bir başka deyişle, bir kişinin kendisinin veya bir başkasının kaderini etkileyebileceğine olan olağandışı inancıdır. Kontrol yanılsamasını ilk araştıran ve tanımlayan araştırmacılardan biri Langer'dır (1975).

Kontrol yanılsaması aynı zamanda bir sonuç üzerindeki kontrolün olduğundan daha yüksek olarak algılanması şeklinde de tanımlanmaktadır (aktaran: Aypay, 2008:27).

Dobelli (2011) ve Arda (2013) tarafından Türkçe'ye çevrilen "Hatasız Düşünme Sanatı: Yapmamanız gereken 52 düşünce hatası" adlı kitabında kontrol yanılsamasını, "objektif bakıldığında üzerinde herhangi bir gücümüz olmayan şeyleri kontrol etmeyi ya da etkilemeyi başarabildiğimize inanma eğilimidir" şeklinde tanımlamaktadır. Yine aynı 
çalışmasında kontrol yanılsamasının temelinin Jenkins ve Ward tarafından 1965 yılında gerçekleştirilen ışık deneyine dayandığını belirtmektedir. Söz konusu deney düzeneği, iki adet şaltere bağlı açık ya da kapalı olan bir 1şıktan oluşmaktadır. Ișık ile şalterin hangi oranda birbirine bağlı oldukları ayarlanabilmektedir. Denekler lambanın tamamen tesadüfi olarak açılıp kapandığı zamanlarda dahi şaltere basarak 1şı̆̆ı bir şekilde etkileyebileceklerini düşünmüşlerdir.

\section{4. İyimserlik}

Çeşitli çalışmalarda iyimserlik önyargısının kendine aşırı güven önyargısının bir bileşeni olduğu ileri sürülmektedir. Örneğin Malmendier ve Tate (2008), kendine aşırı güven önyargısını kişinin kendi yeteneklerini ve olayların sonuçlarını abartması ve genel anlamda beklentilerinde aşırı iyimserlik göstermesi şeklinde tanımlamaktadırlar. Bununla birlikte bu alanda yapılan çalışmalara bakıldığında genel olarak iyimserlik kavramının farklı bir bilişsel önyargı çeşidi olarak ele alındığı görülmektedir. İyimserlik, Weinstein (1980) tarafindan, bireylerin gelecekleri ile ilgili olarak sahip oldukları beklentilerinin gerçekçilikten uzak, ütopik beklentiler olması şeklinde tanımlanmıştır. Kontrol yanılsamasıyla yakından ilişkili olduğunu belirtmiştir (Weinstein, 1980).

\section{Kendine Aşırı Güven Önyargısının Karar Verme Süreçlerine Etkisi}

Kararları etkileyen önyargılar veya yanlılıklar (biases) rasyonel karar vermeden sapmalar olarak görülebilir. Rasyonel bir karar ise Dawes' e (1988) göre aşağıdaki kriterleri karşılamalıdır (Arnott, 1998):

(i) Karar vericilerin mevcut varlıklarını temel alır,

(ii) Verilecek kararın olası sonuçlarına dayanır ve sonuçlar belirsiz olduğunda olasılıklar, olasılık teorisinin temel kurallarını ihlal etmeden tekrar değerlendirilir.

Psikolojik araştırmalar çok sayıda insanın başkaları ile kıyasladıklarında kendi yeteneklerine aşırı güvendiklerini ve gelecekleri ile ilgili sebepsiz bir iyimserlik sahibi olduklarını göstermektedir (Camerer ve Lovallo, 1999). Kendine aşırı güven önyargısının toplumun farklı kesimleri arasında yaygın olarak gözlendiği görülmektedir (Michailova, 2010:5).

Bununla birlikte Glaser ve Weber (2007), kendine aşırı güven önyargısının karar verme süreçleri üzerindeki etkisini inceleyen çalışma sayısının yeterli olmadığını ifade etmişlerdir. $\mathrm{Bu}$ tespitin günümüz için de geçerli olduğu ortadadır. Bu konuda yapılan çalışma sayısının artarak devam etmesine rağmen yeterli görülmemesinin nedeni geleneksel ekonomi ve finans modellerinin ve teorilerinin ekonomik ve finansal sistem içerisinde ortaya çıkan problemlerin çözümünde yetersiz kalmasıdır. Bunun bir sonucu olarak ekonomik ve finansal aktörlerin tam rasyonellik ilkesi çerçevesinde hareket edemeyecekleri görüşü akademik çevrelerde gün geçtikçe daha fazla kabul görmeye başlamıştır.

\section{Kendine Aşırı Güven Önyargısının Ölçülmesi}

Literatürde yer alan çalışmalar, bazı bireylerin diğerlerinden daha fazla aşırı güven düzeyi sergilediğini göstermiştir (Simon ve Houghton, 2003; Yates vd., 1998; Barber ve Odean, 2001; Correll, 2001; Bengtsson, Persson ve Willenhag, 2005; Forbes, 2005).

Cheng (2007), kendine aşırı güvenin, kişilerin yeteneğini, başarı ihtimalini ve edindiği bilgilerin doğruluğunu abartılı şekilde olumlu tahmin etme eğilimi olduğunu belirttiği çalışmasında bu önyargının aynı zamanda insanlarda bulunan en yaygın özelliklerden biri olduğunu belirtmektedir.

Literatüre bakıldığında, kendine aşırı güven önyargısının ölçümünün diğer davranışsal önyargılarda da görüldüğü gibi ampirik araştırmalar için önemli bir zorluk olduğu görülmektedir. Davranışsal finans ve davranışsal işletme finansı literatürleri baz alındığında kendine aşırı güven önyargısının ölçümüne yönelik 3 farklı ölçüm yönteminin kullanıldığı görülmektedir. Bu yöntemler aşağıda görüldüğü gibidir:

(i) Yöneticilerin kişisel yatırımlarını dikkate alan hisse senedi opsiyonu temelli yaklaşım (Malmendier ve Tate, 2005, 2008; Billet ve Qian, 2008; Liu ve Taffler, 2008; Campbell vd., 2011; Malmendier, Tate ve Yan, 2011; Sen ve Tumarkin, 2015),

(ii) Basın portföyü temelli yaklaşım(Malmendier ve Tate, 2005; Hirshleifer, Low ve Teoh, 2012).

(iii) Kalibrasyon skoruna dayalı veya güven aralıklı anket temelli yaklaşım (Ben-David, Graham ve Harvey, 2007; Fischhoff vd., 1977; Fischhoff ve Lichtenstein, 1977).

$\mathrm{Bu}$ yaklaşımlardan opsiyon ve basın portföyü temelli yaklaşımlar, özellikle büyük ölçekli firmaların CEO ve CFO statüsündeki yöneticilerinin kendine aşırı güven önyargısının firma politikaları üzerindeki etkisinin araştırıldığı çalışmalarda kullanılmıştır. Bu yaklaşımların öncüleri Ulrike Malmendier ve Geoffrey Tate' dir (2005a, 2005b, 2008).

Opsiyon kullanımına dayalı aşırı güven ölçeği, kurumsal finans literatüründeki aşırı güvenin ölçülmesi için sıklıkla kullanılan bir ölçektir. Üst düzey yöneticinin (CEO) kişisel servetinin firmasının kendine özgü riskine aşırı maruz kalması CEO'nun kendine aşırı güveninin bir işareti olarak değerlendirilmiştir. $\mathrm{Bu}$ yöntem ilk olarak Malmendier ve Tate (2005) tarafından kullanılmıştır. Hak edilmiş opsiyonların tekrarlı bir şekilde elde tutulması, opsiyon kullanımının ertelenmesi veya aynı firmanın daha fazla hissesinin satın alınması (halihazırda opsiyon sözleşmeleri yoluyla riske maruz kalmasına rağmen) yazarlara göre CEO' nun kendine aşırı güveninin bir göstergesidir. CEO' ların şirket portföyünün gelecekteki performansı ile ilgili inançlarını kişisel portföy işlemlerinden çıkartmaktadırlar.

Malmendier ve Tate ikinci yaklaşımda ise firma dışındakilerin CEO'yu nasıl algıladıklarını anlamaya çalışmaktadırlar. CEO'ları basındaki imajlarına dayalı olarak kendine aşırı güvenli veya rasyonel şeklinde sınıflandırmışlardır. Malmendier ve Tate (2008) eğer bir CEO tutumlu, muhafazakâr, temkinli, pratik, güvenilir veya istikrarlı gibi tanımlayıcılara göre güvenli veya iyimser şeklinde sıklıkla tanımlanıyorsa o kişiyi kendine aşırı 
güvenen olarak sınıflandırmışlardır. Bu ölçek, CEO ile ilgili basında çıkan haberlerden el yordamıyla toplanan verilerden oluşmuştur. Örneklem ise 2001'den 2007'ye kadar tüm Fortune 500 firmalarını kapsayacak şekilde oluşturulmuştur (Hribar ve Yang, 2016).

Galasso ve Simcoe (2010) yaptıkları çalışmada CEO'ların kendine aşırı güven düzeylerini kişisel yatırımlarını dikkate alarak firmalarının gelecekteki performansı hakkında ortaya koydukları inançları üzerinden tespit etmeye çalışmışlardır. Buna göre hisse senedi opsiyonlarının tamamına hak sahibi olduktan sonra karda olan opsiyonu uzun süre elinde tutan CEO lar kendine aşırı güvenen CEO şeklinde sınıflandırılmıştır. Bir alım opsiyonunun kullanım fiyatı opsiyona konu olan varlık fiyatından (spot fiyattan) düşükse bu opsiyona karda veya asli değerli opsiyon denir. Satım opsiyonunda ise karda opsiyon söz konusu olabilmesi için, opsiyona konu varlığın kullanım fiyatının spot piyasa fiyatından yüksek olması gerekir.

Malmendier, Tate ve Yan (2011) CEO'ların ellerinde bulundurdukları opsiyon varlıklarına ilişkin verileri kullanarak kendine aşırı güveni ölçmüşlerdir. CEO' lar ellerindeki hisse senedi opsiyonlarını hak kazanma dönemlerinden sonra karda olmalarına rağmen kullanmayıp son kullanım tarihlerine kadar ellerinde bulundurmayı tercih etmektedirler. Hak kullanmada yaşanan bu gecikme Malmendier ve Tate $(2005,2008)$ tarafindan Longholder şeklinde ifade edilmiştir. Bu durumun ortaya çıkmasının sebebini ise söz konusu CEO'ların firmalarının gelecekteki nakit akışı ortalamalarını abartılı tahmin etmeleri şeklinde ifade etmişlerdir. Malmendier ve Tate aynı zamanda alternatif bir ölçek olarak, son kullanma tarihinden beş yıl öncesine kadar yüksek oranda (\%67) karda olmasına karşın opsiyon kullanmayan CEO'ları belirlemiş ve bunları Holder67 şeklinde tanımlamışlardır. Ayrıca bu opsiyon portföyü temelli ölçümlerine bir alternatif olarak, CEO'ların davranışlarını iş dünyası dergileri ve gazetelerinde "kendine güvenen" ya da "iyimser" şeklinde yer alan tasvirlerine dayanarak belirlemişlerdir.

Psikolojik araştırmalar, anket yönteminin uygulanarak kendine aşırı güven önyargısının ölçüldüğü araştırmalarda ve sorulan soru niteliğinin genel olarak zor sorulardan oluştuğu anketler kullanıldığında, kendine aşırı güven önyargısının daha belirgin olarak ölçüldüğünü göstermiştir (Michailova, 2010:15).

Psikolojik araştırmaların bulguları, verilen yargılarda gözlenen önyargıların içinde bulunulan duruma göre farklılaştı̆̆ını göstermektedir. Örneğin, cinsiyet açısından bakıldığında, bir gruba sorulan sorular diğer grup için de aynı şekilde sorulduğunda, gruplardan biri cevap vermede daha fazla zorlanabilmektedir. Ya da araştırmaya katılım noktasında gruplardan birinin yeteri kadar motive olamaması bir etken olabilir. Başka bir ifadeyle yöneltilen soru ya da yapılan deney, gruplardan birinin diğeri kadar ilgi alanına girmeyebilir. Kendine aşırı güveni farklı toplum kesimleri üzerinden araştıran araştırmacılar, Russo ve Schoemaker (1992)'ın çalışmalarını takiben kendine aşırı güvenin değerlendirilmesinde aralıklı eleme sorularını kullanmışlardır. Bununla birlikte, bu tür soru kalıplarının olağanüstü düzeyde kendine aşırı güven üretme eğilimi gösterdiği belirtilmektedir (Klayman vd., 1999).

\subsection{Güven Aralıklı Anket ve Kalibrasyon Skoru} Yöntemiyle Kendine Aşırı Güvenin Ölçülmesi

Pulford (1996), Klayman vd. (1999) ve Kufepaksi (2007) tarafından yapılan çalışmalarda kişilerin kendine aşırı güven seviyelerinin kalibrasyon testi ile belirlenebileceği belirtilmiştir. Kalibrasyon testi bu amaçla özel olarak tasarlanmış belirli sorulardan oluşan ankete dayanan ve aşırı güven düzeyinin bilgi düzeyi ve güven seviyesinin kombinasyonunu test etmek ve tanımlamak için kullanıldığ bir yöntemdir. Pulford (1996) kendine aşırı güven önyargısının ölçülebilmesi için öncelikle, sorulan önyargı sorusuna verilen cevabın doğru ya da yanlış olduğunu onaylayan bir yargı ve bu yargının da güven derecesinin bir ölçeği olması gerektiğini belirtmektedir. Dolayısıyla katılımcılara sorulacak her bir sorunun karşısında bir genel kabul gören doğru ve yanlış cevap yargısı ve cevaplayıcının verdiği cevaba duyduğu güveni ifade eden bir ölçek olmalıdır. Pullford (1996) aşırı güvenin ölçülmesi için öncelikle, verilen cevabın doğru veya yanlış olduğunun doğrulanabileceği bir yargıya ve bu yargının güven derecesinin bir ölçüsüne sahip olunması gerektiğini belirtmektedir. Varılacak bir yargı veya verilecek bir karara duyulan güvenin derecesi, açıklayıcı terimlerle ya da daha nicel yöntemlerle ölçülebilir. Bu nedenle güven, sıklıkla yargının doğruluğundaki öznel olasılığın bir tahmini olarak ölçülür (Pulford, 1996).

Bir yargı ya da karar durumunda güven, açıklayıcı terimler ile ölçülebileceği gibi daha niceliksel yollarla da (örneğin, inanç ya da kesinlik durumunun kuvvet derecesinin varılan yargının doğruluğunun değerlendirilmesinde sübjektif olasılık tahminine dönüştürülmesi) ölçülebilir. Güven genel olarak, belirtilen bir yargının doğruluğuna ilişkin sübjektif olasılık tahmini olarak ölçülür (Pulford, 1996). Yani cevaplayıcının verdiği cevabın doğru olduğuna olan güveninin sübjektif olasılık tahminidir. Sübjektif olasılık tahmini, istatistiki verileri kullanma olasılığı olmadığı durumlarda (örneğin, üretilecek bir ürüne karşı oluşacak talep hakkında fikir sahibi olunabilir ancak hesaplanamaz) yapılan tahminlerdir. Sübjektif tahminlerin meydana getirdiği olasılık dağılımına ise "sübjektif olasılık dağılımı" denir (Bierman ve Smidt, 1970).

Bir bireyin yargısının doğru olması ihtimalinin tahmininin sübjektif olasılığı, günlük hayattaki terminolojide kullanılan "verilen cevabın doğruluğundan emin olma duygusu" ile ifade edilebilir. Örneğin, "Bu sorunun doğru cevab1 \%95 olasılıkla A şıkkıdır", şeklindeki bir ifade "Bu sorunun doğru cevabının A şıkkı olduğundan neredeyse tamamen eminim" şeklindeki ifadeyle, sorunun cevabına yönelik, paralel bir inanç düzeyine işaret etmektedir. Her iki ifadede de küçük bir miktar hata payının bırakıldığı görülmektedir. Bununla birlikte "Bu sorunun cevabının A şıkkı olduğuna \%100 eminim.” ya da “ A şıkkı kesinlikle doğru şıktır." şeklindeki ifadeler ise hiçbir şüpheye yer bırakmayan ifadelerdir (Tekin, 2015).

\subsection{Tam Aralıklı, Yarı Aralıklı ve Kesikli Aralıklı Ölçekler}

Verilen cevaba duyulan güvenin ölçümünde üç çeşit ölçekten yararlanılmaktadır. Bunlar, tam aralıklı, yarı aralıklı ve kesikli aralıklı ölçeklerdir. Bir sorunun yargılanması sürecinde kişilerin kendi cevaplarını üretmesi gerekiyorsa ve 
sonra verilen cevabın doğru olduğuna duyulan güvenin değerlendirilmesi isteniyorsa ya da yöneltilen sorunun cevabı olarak geniş bir cevap yelpazesi olan durumlarda \%0100 tam aralık ölçeğinin kullanılması tavsiye edilir. Bu ölçek kullanıldığında, örneğin, A şıkkına olan \%55 güven aynı zamanda B şıkkına duyulan $\% 45$ güveni ifade eder. Bu prensip şu şekilde genelleştirilmektedir; T tercih edilebilecek cevap ya da seçenek sayısı olduğunda güven ölçüm ölçeği 100/T' den \%100' e kadar genişletilebilmelidir (Adams ve Adams, 1961). Tam aralık ölçeği aynı zamanda deneklerin ya da cevaplayıcıların verdikleri cevaplara olan güvenlerinin yönünün cevabın doğru olduğu yönünde olması durumlarında sınırlı tercihler ya da alternatifler için de kullanılabilir (Pulford, 1996).

Yarı aralıklı ve kesikli aralıklı ölçeklerde ise sübjektif güven sürekli değişkeni, kesikli aralıklar içerisine ayrılabilir ve doğru cevapların objektif oranı her aralık için ortalama güvene karşı bir grafik üzerinde görülebilir. Bu durum, kalibrasyon eğrisi olarak adlandırılmaktadır. Grafik 1'de yarı aralıklı ölçeğin (0.5'ten 1.0'a) kullanıldığı kalibrasyon eğrisi görülmektedir. Konuya ait sadece iki cevap mevcuttur. Grafikte, güvenin tamamen kesinlik durumuna eşit olduğu, mükemmel kalibrasyonun oluştuğu ve herhangi bir şekilde kendine aşırı güven ya da güvensizlik durumlarının söz konusu olmadığı "kimlik çizgisi" görülmektedir. Eğer doğruluk oranı, sübjektif olasılıktan (güven) küçük ise kendine aşırı güvenin ortaya çıktığı söylenir. Tersi durumda ise güvensizlik söz konusudur (Pulford, 1996).

Grafik 1. Yarı Aralıklı Ölçeklerde Kalibrasyon Eğrisi

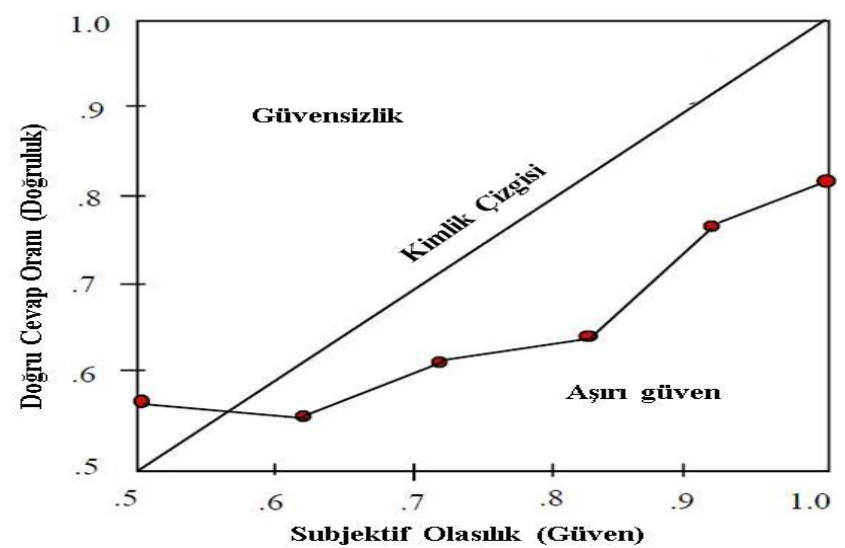

Kaynak: Pulford (1996)

Örneğin, ortalama güvenin \%70'e eşit olduğu durumda göreli doğruluğun yaklaşık \%70 olması gerekir. Böyle bir durumda güven ve doğruluk arasındaki farklılık istatistiksel olarak hesaplanabilir. $\mathrm{Bu}$ tür tutarsızlığın ölçüldüğü yöntemlerden biri kalibrasyon skorudur (Pulford, 1996).

\subsection{Kalibrasyon Yöntemi}

Kalibrasyon skoru hesaplanırken, ilk olarak güven değişkeni kesikli aralık ya da kategorilere (örneğin 0.6-0,69 Aralığına) bölünür. Daha sonra güven ve doğru cevap oranı arasındaki tutarsızlık tüm kategoriler için hesaplanır. Koriat, Lichtenstein ve Fischhoff (1980) kalibrasyon skorunun, Grafik 1'de görülen veri noktaları ile kimlik doğrusu arasındaki karesel farkların ağırlıklı ortalamaları olduğunu belirtmektedirler (Koriat, Lichtenstein ve Fischhoff, 1980:110). Bu ölçeğe göre kusursuz bir şekilde kalibre olmuş bir kişinin skoru "sıfır"dır. Sonuç olarak kalibrasyon
(K) (güven düzeylerine $\left(r_{t}\right)$ yaklaşık olarak karşılık gelen gözlenen doğru cevap oranlarının varyansı $c_{t}$, güven kategorisindeki $(t)$ cevaplarin sayıs $n_{t}, T$ kullanılan cevap kategorilerinin toplamı ve $N$ toplam cevaplar ise) aşağıdaki formül ile hesaplanır (Murphy, 1973; Jonsson ve Allwood, 2003; Pulford, 1996);

$$
K=\frac{1}{N} \sum_{t=1}^{T} n_{t}\left(r_{t}-c_{t}\right)^{2}
$$

Bununla birlikte kendine aşırı güven önyargısının ölçeği, doğruluk ve tutarsızlık ölçeğinden biraz daha farklıdır. Kendine aşırı güven önyargısının ölçeğinde, önyargının, aşırı güvenin mi yoksa güvensizliğin mi göstergesi olduğunu belirtmek için, pozitif ve negatif işaretler muhafaza edilir. Kendine aşırı güven önyargısı aşağıdaki formül ile hesaplanır (Murphy, 1973; Jonsson ve Allwood, 2003; Pulford, 1996),

$$
\text { Kendine Aşırı Güven/Güvensizlik }=\frac{1}{N} \sum_{t=1}^{T} n_{t}\left(r_{t}-c_{t}\right)
$$

$\mathrm{Bu}$ formül biraz daha basit bir şekilde ifade edilirse, kendine aşırı güven, ortalama güven skoru x ile ortalama doğru cevap oranı c (doğruluk) arasındaki farka eşit olacaktır (Pulford, 1996).

$$
\text { Kendine Așırı Güven/Güvensizlik = x - c }
$$

Belirsizlik altında karar verme konusu bağlamında yapılan çalışmaların belirttiği üzere bireyler çoğunlukla kendine aşırı güvene sahiptirler. Kahneman ve Tversky (1973), bu olguyu birbiriyle ilişkisi olmayan tahminler ile ölçerken; Alpert ve Raiffa (1982), geniş ve dar güven aralıkları bağlamında ele almışlardır. Ancak bu önyargının çoğunlukla kalibrasyon çalışmaları ile ortaya çıkarıldığı ya da ölçüldüğü görülmektedir (Brenner, Koehler, Liberman ve Tversky, 1996: 212).

Bununla birlikte kalibrasyon çalışmaları, bireylerin verdikleri cevaplara ya da vardıkları kanıya olan güvenlerinin çoğunlukla doğru cevap ya da yargı oranından çok daha yüksek olduğunu ortaya koymaktadır (Keren 1997; Lichtenstein vd., 1982; McClelland ve Bolger, 1994; Yates, 1990; Brenner vd., 1996). Brenner vd. (1996) kendine aşırı güvenin, ortalama güven ile genel doğru arasındaki fark olarak ifade edildiğini belirtmektedirler. Aynı zamanda, kendine aşırı güven ile doğruluk arasında negatif bir korelasyonun varlığından söz etmektedirler.

Kişilerin kendine aşırı güvenlerinin belirleyicisi, soruların nasıl seçildiğinden çok, seçilen soruların zorluk seviyeleridir. Soruların zorluk seviyeleri arttıkça kendine aşırı güven düzeyi de artmaktadır (Soll, 1996; Brenner vd.,1996:213, Klayman vd., 1999:217). Zorluk ise doğru cevapların yüzdesi olarak ölçülür (Gigerenzer vd., 1991:506). Klayman vd. (1999), kendine aşırı güven önyargısının, güven aralıklı yargı durumlarını ve kalibrasyon içeren anketler kullanıldığında daha güçlü ölçüldüğünü ifade etmektedirler. Bunun nedenini, kendine aşırı güvenin bu yöntemle daha açık bir şekilde ortaya çıkması, etki alanlarının (sorular ya da yarg1 durumları) ve bireyler arasındaki farklılıkların güçlü bir şekilde ortaya konulması olarak açıklamaktadır. Bununla birlikte kalibrasyon çalışmalarını içeren literatürdeki bulgulara bakıldığında, genel bilgi sorularına cevap verilmesi istendiğinde kişilerin 
güven aralıklarını genellikle çok dar tuttuğu görülmüştür (Fellner ve Krügel, 2012).

Kalibrasyon skoru yöntemini çok sayıda araştırmacı yaptıkları çalışmalarda kullanmıştır (Lichtenstein, Fischhoff ve Phillips, 1982; Alpert ve Raiffa, 1982; Klayman, Soll, Gonzales-Vallejo ve Barlas, 1999; Johnson ve Allwood, 2003; Biais, Hilton, Mazurier ve Pouget, 2005; Parker ve Fischoff, 2005; Russo ve Schoemaker, 1992; Keh vd., 2002; Michailova, 2010).

Kalibrasyon skoru yönteminin kullanıldığı çalışmalarda anketler 10 sorudan oluşmakta ve katılımcıların kalibrasyon skorları bu 10 soruya verdikleri cevap aralıklarının doğru cevabı kapsama sayısına göre hesaplanmaktadır. Dolayısıyla KALSKO aşağıdaki formül ile hesaplanmaktadır (Klauss, 2006; Glaser ve Weber, 2007);

Kalibrasyon $=1-\frac{10-\text { doğru cevabı kapsamayan cevap aralığ sayısı }}{9}$

İyi kalibre olmuş bir katılımcı sadece "1" hata yapacağ 1 için KALSKO "0" olacak ve bu katılımc1 "rasyonalite" sergileyecektir. Eğer katılımcının tüm sorular için verdiği cevap aralığı doğru cevabı kapsamayacak şekilde verilmiş ise bu katılımcı "tam kendine aşırı güven (overconfidence)" sergileyecektir. Bunun tersi olarak tüm cevaplar doğru cevabı kapsayacak şekilde verilmiş ise bu katılımcı "kendine güvenmeyen (underconfidence)" katılımc1 olarak karakterize edilir (Russo ve Schoemaker, 1992; Simon, Houghton ve Aquino, 2000; Fitzzsimmos ve Douglas, 2005; Klauss, 2006).

\subsection{Diğer Yöntemler}

\subsubsection{Yargllayıcı Kendine Aşırı Güven}

Fellner ve Krügel (2012) kendine aşırı güvenin, davranışsal ekonomik ve finans modellerinde, genellikle, sinyallerin güvenilirliğinin yanlış algılanması sonucu ortaya çıktığını ve özel bilgilerin aşırı ağırlıklandırılmasına neden olduğunu belirtmektedirler. $\mathrm{Bu}$ modellerin ampirik testlerinin ise genellikle beklendiği gibi sonuçlanmadığını belirtmektedirler. Araştırmacılara göre, bu türden çalışmalar belirli bir aşırı güvenme türünün, yani "yanlış ayarlamanın" altındaki özelliği içerdiğini varsaymaktadır.

Felnner ve Krügel (2012) çalışmalarında kendine aşırı güveni 3 aşamada ölçmüşlerdir. Söz konusu aşamalar; genel bilgi soruları, zaman serisi tahminleri ve sinyal tabanlı tahminlerdir. Araştırdıkları ilk hipotez; "genel bilgi soruları ile ölçülen eksik kalibrasyon, zaman serisi tahmini görevleriyle ölçülen eksik kalibrasyonla ilgilidir" şeklindedir. İkinci hipotez ise "genel bilgi ve zaman serileri soruları sonucunda eksik kalibre olmuş kişiler aynı zamanda sinyal duyarlılığını fazla ölçtügünden, kendi özel bilgilerine aşırı ağırlık verme eğilimindedir” şeklindedir.

Çalışmalarında ilk olarak katılımcıları her üç aşamadaki yargılarının doğruluğuna göre sınıflandırmışlar ve ortalama aşırı güvenin genel bir görünümünü sunmuşlardır. Daha sonra, üç aşırı güven ölçeğini ilişkilendirerek hipotezlerini test etmişlerdir. Sonuç olarak, sinyal doğruluğunun algılanışının ve eksik kalibrasyon ölçümlerinin ilişkisiz oldukları sonucuna ulaşmışlardır. Bu nedenle, ekonomi ve finans alanlarında ve kendine aşırı güven literatüründeki teorik yaklaşımları test etmek için, iyi kurgulanmış eksik kalibrasyon önyargısına güvenilemeyeceğini belirtmektedirler.

\subsubsection{Parkinson Tahmini}

$\mathrm{Bu}$ yöntem Huisman, Van der sar ve Zwinkels (2012) tarafından yatırımcıların kendine aşırı güvenlerinin tespit edilmesi amacıyla uygulanmıştır. Parkinson tahminini, yatırımcının aşırı güvenini ortaya çıkarmak için hisse senedi tahmininin etrafındaki aşırı sınır noktalarına dayanılarak uygulanmıştır. Çalışmalarında Hollanda'nın en büyük bankalarından birinde hesap sahibi olan bir grup bireysel yatırımcının hisse senedi piyasasındaki tahminlerine aşırı güvenip güvenmediğini doğrudan test etmişlerdir. Güven ölçekleri, Aralık 2009'dan Ekim 2010'a kadar iki haftada bir tekrarlanan bir anket çalışmasından alınmıştır. $\mathrm{Bu}$ yaklaşımda, Parkinson (1980) oynaklık tahmini kullanılması nedeniyle Parkinson Tahmini adı verilmiştir. Bu ölçek, iki haftalık Amsterdam Değişim (AEX) borsa endeksi tahmini çevresinde en yüksek ve en düşük sınırların tahminlerine dayanmaktadır. Kendine aşırı güven düzeyini ölçmek için, AEX volatilite endeksi (VAEX) beklenen oynaklık kriteri olarak kullanılmıştır.

Yatırımcılara e-posta üzerinden ankete katılım daveti gönderilmiştir. Anketin araştırmacılar tarafından hazırlanan bölümündeki soru grubu şu şekildedir: "Bugün, AEX Endeksi XXX'de kapandı", Burada XXX şeklinde gösterilen AEX Endeksinin kapanış fiyatıdır. Daha sonra yatırımcılardan aşağıdaki soruları yanıtlamaları istenmiştir:

(i) AEX Endeksi dd-mm-yyyy ${ }^{1}$ tarihinde ne seviyede kapanır?

(ii) AEX Endeksi, dd-mm-yyyy tarihinde en yüksek hangi seviyede kapanır?

(iii) AEX Endeksi dd-mm-yyyy tarihinde en düşük hangi seviyede kapanır?

İkinci soru seti ABN Amro bankası tarafından tasarlanmıştır. Bunlar örneğin "Yeni yılın sana ne gibi yenilikler sunacağını düşünüyorsun?" veya "Şu anda en çok beğendiğiniz hisse senedi hangisidir?” gibi açık uçlu sorulardır.

Sonuçlar, ankete katılan küçük bireysel yatırımcıların belirgin bir kendine aşırı güven eğilimi sergilediklerini göstermiştir. Yatırımcıların, teklif edilen opsiyon fiyatlarından elde edilen gösterge dalgalanmalarına karşı aşırı güven sahibi olduklarını ortaya koymaktadır.

\subsubsection{Hisse Senedi Sahipliği}

Kendine aşırı güven firma boyutunda ele alındığında yönetici kendine aşırı güveni gündeme gelmektedir. Yöneticilerin şirketlerinin öz sermayesindeki paylarının artmakta olması daha önce bahsedilen kontrol yanılsaması olgusuna yol açabilmektedir. Yöneticilerin, şirketlerinin performansı ve büyümesi üzerindeki etkilerine gerçekte olduğundan daha fazla anlam yüklemeleri nedeniyle, şirketin gelecek performansı konusunda yüksek seviyeli iyimserlik sergileyebilir, hisse senetlerinin getirisini abartılı tahmin

1 dd-mm-yyyy, anketten iki hafta sonra Cuma gününü ifade eden belirli bir tarihtir. 
edebilir ve çeşitlendirilmemiş portföyü elinde bulundurmaya devam ederek ve şirketin nasıl yatırım yapması ve büyümesi gerektiği gibi konulardaki kendi vizyonunu uygulayarak olası riskleri hafife alabilirler (Stechyshyna, 2017).

İçeriden bilgi sahibi olarak kar elde etmeyi beklemek ek riskler doğurabilir. Bilginin asimetri sorunu hesaba katıldı̆̆ında, şirketlerin yeni politikalarına veya birleşmesatın alma ya da büyük bir yatırım girişimi gibi duyurularına yönelik piyasa tepkisini önceden tahmin etmek genellikle zordur. Bu nedenle, içsel bilgilere dayanarak yatırım yapmak oldukça cüretkâr bir davranıştır ve bu durum özellikle hisse senedi performansı zayıfsa, kendine aşırı güven işareti olarak düşünülebilir. Bu duruma ilişkin, sinyal hipotezi alternatif bir açıklama olabilir (Malmendier ve Tate, 2002). Ayrıca yeterli düzeyde çeşitlendirilmemiş bir portföy, aşırı güvenin bir işareti olarak görülebilir ve derecesi yöneticilerin duyurudan bir yıl önce sahip olduğu öz sermaye yüzdesiyle ölçülür (Stechyshyna, 2017).

Stechyshyna (2017) yaptığı çalışmasında yöneticilerin aşırı güven ve risk alma tutumlarının çapraz sektörler arası satın almalar üzerindeki etkisi üzerinde durmuştur. Çalışmada kendine aşırı güveni, 4 farklı şekilde ölçmüştür. İlki, hisse senedi opsiyon uygulamasıyla ilgilidir. Buna göre, hisse senedi opsiyonları karda opsiyon (in the Money) ise ve bir önceki yıla oranla toplam sayı 5 ' $\mathrm{i}$ aşmış ise CEO kendine aşırı güvenli olarak kategorize edilmiştir. İkincisi, CEO'nun şirkette geçirdiği yılların (pozisyona bakılmaksızın) yaşına oranıdır. Üçüncüsü, cinsiyet ve yaş yaklaşımlarıyla ilişkilidir ve yaş gruplarına göre erkeklerde testosteron düzeyi (Vermeulen, 1996) ile ölçülmüştür. Son olarak CEO'nun sahip olduğu şirket hisselerinin \% 'sinin aşırı güven için bir gösterge olduğu varsayılmıştır.

\subsubsection{Finansal Okuryazarlık}

Xia, Wang ve Li (2014) tarafından yapılan çalışmada katılımcılara finansal okuryazarlığı ölçen bir anket uygulaması yapılmıştır. Yazarlar finansal okuryazarlığı sübjektif (öznel) ve objektif (nesnel) olmak üzere iki başlık altında araştırmışlardır. Araştırmacılar öznel finansal okuryazarlığı ölçmek için katılımcılara hisse senedi, yatırım fonları ve tahvillerle ilgili "Kendinizin veya ailenizin aşağıdaki finansal yatırım araçlarına aşina olma düzeyinizi nasıl değerlendirirsiniz?" sorusunu sorarak ölçmüşlerdir. Ankete katılanlardan, 1' in "aşina değilim" ve 5' in "çok aşiyanım" seçeneklerini temsil ettiği belirtilerek, 1 ile 5 arasındaki ölçeği işaretlemeleri istenmiştir. Daha sonra her üç sorunun ölçek üzerinde değerlendirilmesi ile elde edilen değerler, 3 ile 15 teorik aralığında olmak üzere öznel finansal okuryazarlık endeksini (öznel FL) ortaya koymak için bir araya getirilmiştir.

Objektif finansal okuryazarlık ise çeşitli ülkelerde yapılan çalışmalardan hareketle hazırlanmış sorulardan oluşan bir anket ile ölçülmüştür. Söz konusu ankette 6 soru yer almaktadır ve her biri kişilerin çeşitli finansal olaylara ilişkin bilgisini ölçmektedir. Objektif finansal okuryazarlık puanı (nesnel FL), altı sorudan elde edilen puanlar toplamı ile türetilmiş ve teorik olarak 0-6 arasında değişen aralıklara sahiptir. Ayrıca bu ankette yer alan sorulara ilişkin cevap seçeneklerine kendine aşırı güvenin ölçülebilmesi amacıyla "bilmiyorum" seçeneği de dahil edilmiştir. Eğer katılımcı bilmiyorum seçeneği haricindeki diğer iki seçenekten birini tercih etmiş ve bu seçenek "yanlış" cevabı ifade ediyorsa bu katılımcı "kendine aşırı güvenen" şeklinde tanımlanmıştır. Örneğin "Piyasada faizler düşerse tahvil fiyatları ne olur ?" şeklindeki bir soruya katılımcı "bilmiyorum" seçeneğini tercih etmek yerine doğru cevaptan emin bir şekilde "düşer" cevabını vermiş ise bu kişi "kendine aşırı güvenen" olarak sınıflandirılmıştır.

3122 katılımcıya uygulanan anketler sonucunda öznel okuryazarlık ortalaması 9,467, nesnel okuryazarlık ortalaması ise 3,093 bulunmuştur. Buna göre nesnel finansal okuryazarlı puanı 3,093'ten az ve öznel finansal okuryazarlık puanı 9,467'den yüksek olan katılımcılar Probit Regresyon analizi için kendine aşırı güvenen=1, aksi durum $=0$ şeklinde kodlanmıştır.

Çalışma sonucunda kendine aşırı güvenen bireylerin hisse senedi piyasalarında işlem yapma olasılıklarının daha yüksek olduğu sonucuna varılmıştır. Bu oran yaklaşık \% 20 civarındadır. Çalışmanın bir başka sonucuna göre, kendine aşırı güvenen katılımcıların borsa katılım oranlarının, objektif ve sübjektif finansal okuryazarlığa sahip katılımcıların katılım oranlarına benzediğidir.

\section{Kendine Aşırı Güvenin Olumsuz Etkileri ve Bu Etkilerden Sakınma Yolları}

Howard (1983) ve Johnson (2004) kendine aşırı güvenin savaşların bir nedeni olduğunu belirtmektedirler. Kendine aşırı güvenin, Çernobil'deki nükleer kaza ve Uzay Mekiği Challenger'ın patlamasıyla ilişkili olduğunu belirtecek kadar önemine dikkat çeken çalışmalar mevcuttur (Aktaran: Moore ve Healy, 2007). Plous (1993), yargiya varmada ve karar vermede sorun yaşamamanın, kendine aşırı güvenden daha yaygın olduğunu ve daha büyük bir felakete neden olabileceğini belirtmektedir. S1k rastlanan genel bir olgu olması ve önemi nedeniyle kendine aşırı güven araştırmaları psikoloji alanı dışında da geniş ölçüde etkili olmuştur (Moore ve Healy, 2007).

Kendine aşırı güven, insanlarda sık rastlanan bir karar verme yanlılığıdır (Shiller, 1999). Kendine aşırı güvenin etkisi sadece finansal piyasalardaki işlemlerde değil hayatın her alanında görülmektedir. $\mathrm{Bu}$ nedenle kendine aşırı güvenin genel bir problem olduğu söylenebilir. Problem olarak nitelendirilmesi tabi ki insanların kötümser olmaları gerektiğini ifade etmemektedir. Ancak kişilerin kendilerine olan anlamsız ve aşırı güvenlerinin de sıklıkla hata yapmalarına neden olduğu literatürde yapılan çalışmalarla ortaya konulmuş bir olgudur. Bireylerin kendilerine aşırı düzeyde güven duyarak hareket etmelerinin altında yatan psikolojik nedenlerin anlaşılması bu önyargının olumsuz etkilerinin engellenmesine de yardımcı olacaktır.

Güven faktörünü kendine aşırı güveni dikkate alarak kategorize ettiğimizde, güvensizliği sakıncalı bir davranış türü, özgüveni motive edici olumlu bir davranış türü, kendine aşırı güveni ise riskli ve sakıncalı bir davranış türü olarak değerlendirebiliriz. Bununla birlikte az da olsa kendine aşırı güvenin güven eksikliğinden daha iyi olduğu söylenebilir. Pikulina, Renneboog ve Tohler (2014) güçlü düzeyde aşırı güvenin çok fazla çabanın ve paranın yatırım için harcanmasına neden olduğunu bununla birlikte yetersiz kendine güvenin ise yetersiz çaba ve yetersiz yatırımı beraberinde getirdiğini buna karşın orta düzeyde aşırı güvenin ise doğru kararlar verilmesini sağladığını 
belirtmektedir. Bu nedenle optimal düzeyde sahip olunan kendine aşırı güven, motivasyonu arttırıp kişiyi kısa vadeli olumsuz sonuçlarla karşılaştığında dahi karlı uzun vadeli hedeflere ulaşmaya teşvik edeceğinden değerli bir bireysel özelliktir (Pikulina vd., 2014). Wang (2001) dinamik ve evrimsel bir modelde, rasyonel olmayan yatırımciların uzun vadede varlıklarını devam ettirip ettiremediklerini incelediği çalışmasında orta düzeyde kendine aşırı güvenen yatırımcıların uzun dönemde varlıklarını devam ettireceklerini diğerlerinin ise elimine olacaklarını belirtmektedir. Ayrıca, riskli varlığın değerinin (temel risk) varyansı büyük olduğunda, orta derecede kendine aşırı güvene sahip olan rasyonel olmayan yatırımcılar pazara hakim olma eğilimindedir. Wang aynı çalışmasında, aşırı güvenin yatırımcılar iyi sinyaller aldıklarında daha fazla varlık satın almalarına ve kötü sinyallerde ise daha fazla satmalarına neden olduğunu belirtmiştir. Sonuç olarak, kendine aşırı güvenen yatırımcılar ve rasyonel rakipleri arasındaki talep farklılığı, varlığın değeri ile pozitif bir korelasyona sahip olma eğilimindedir ve böylece kendine aşırı güvenen yatırımcılar daha yüksek bir beklenen getiri eğilimi gösterir.

Psikolojik araştırmalar, düzeyleri bireyden bireye farklılık gösterse de hemen hemen herkesin bir dereceye kadar kendine aşırı güven davranışsal önyargısına sahip olduğunu göstermiştir. Daha önce de belirtildiği gibi bireylerin yarısından fazlası ortalama bir sürücüden üstün sürüş yeteneklerine sahip olduğunu düşünmektedir. Aynı zamanda bireyler kendi yatırım kararlarına, inançlarına ve görüşlerine karşı çok fazla güven duymaktadırlar. Ancak, bazı şeyler kötüye gitmeye başladığında, bunun sadece kötü şanstan dolayı ortaya çıktığını öne sürmektedirler. Finansal piyasalarda işlem yapan birçok yatırımcı en kazançlı yatırımları seçebileceklerine olan aşırı inançlarının tuzağına düşmektedir. Yapılan araştırmalar, kazançlı yatırımları seçmenin profesyonel yatırımcılar için bile inanılmaz derecede zor olduğunu gösterirken bu tip yatırımcılar, servetlerinin önemli bir kısmını sadece tek bir yatırım alternatifine yatırarak (örneğin tek bir firmanın hisse senedine) büyük risk üstlenebilmektedir (Sutherland, 2015).

Bireylerin, verecekleri kararın tamamen sahip oldukları güvenilir bilgiye ve yeteneklerine dayanılarak mı yoksa kendine aşırı güvenin etkisi altında abartılmış bilgiye ve yeteneğe dayanılarak mı verdiklerini karar aşamasında değerlendirmeleri kendine aşırı güvenin olumsuz etkilerinden sakınmada bir çözüm yolu olabilir. Verilecek karar konusuyla ilgili bilgisine ve uzmanlığına güvenilen kişilerden destek alınması sayılabilir. Bunun yanı sıra kişilerin şans olgusunu da dikkate almaları gerekir. Aldıkları başarılı sonuçları, tamamen kendi yetenek ve bilgilerine bağlamak yerine şansın da bir etken olduğunu ele alarak değerlendirmeleri daha gerçekçi bir yaklaşım olacaktır. Şans faktörü ile bağlantılı olarak kişilerin bir veya birkaç başarılı sonuç sonrasında aynı türden yatırım alışkanlıklarına devam etmemeleri de kendine aşırı güvenin olumsuz sonuçlarından korunma imkânı tanıyacaktır. Söz konusu olan bir yatırım projesi ise söz konusu projenin karmaşıklığını anlayabilmek amacıyla yeterli zamanın ayrılması sonradan kötü süprizlerle karşılaşmaktan daha iyi olacaktır. Bir projenin karmaşıklığının anlaşılmasından sonra beklenmedik olumsuz durumlar için fazladan zaman ve kaynak sağlanması gerekir. Ancak bu fazladan zaman ve kaynağın işletmeye rekabet edebilme gücünü kaybettirmeyecek optimal bir seviyede olması önemlidir (Latumahina, 2010).

Yapılan yatırımların kayıtlarının tutulması ve uzun vadede bu kayıtlara geri dönülerek bir karşılaştırma yapılması koruyucu bir etken olabilir. Bu şekilde yatırımcı aslında o kadar da başarılı olmadığını görebilecektir. Bunun yanında tecrübe unsuru da ayrıca önemli bir olgudur. Yapılan araştırmalar yatırımcıların büyük çoğunluğunun yatırım becerisi bağlamında kendilerini ortalamanın üzerinde gördüğünü ortaya koymuştur. Bununla birlikte kurumsal yatırımcıların ve başarılı finansal yatırım kurumlarının yayınladıkları raporlara ve hesaplama modellerine hakim olan profesyonel fon yöneticilerinin dahi piyasalarda çoğu zaman yenilgiye uğradıkları bilinen bir gerçektir. Bu konuda Latumahina (2010) tarafindan Robert Shiller' a atfen anlatılan bir hikâye şöyledir: 20. yüzyılın başlarında Yale Üniversitesi' nde profesör olan ve 1929' da borsanın 'sürekli yüksek platoda" olduğunu söyleyen Irving Fisher borsaya çok fazla yatırım yapmış ancak 1929 buhranında çok fazla para kaybetmiştir. Yale Üniversitesi Fisher' ın evini almak zorunda kalmıştır ve sokakta kalmaması için kendisine kiralamıştır. Fakat Fisher bütün bu olanlardan sonra dahi görüşünü değiştirmemiştir. Hala haklı olduğu konusunda 1srar eden Fisher varlıklı akrabalarından ödünç para alarak yatırım yapmıştır ve hepsini kaybetmiştir. $\mathrm{Bu}$ nedenle verilecek kararlarda başarısızlık olasılığının dikkate alınmaması kendine aşırı güvenin olumsuz sonuçlarını da beraberinde getirecektir (Marotta, 2008).

Marotta (2008) kendine aşırı güvenin aşağıda sıralanan ve yatırımlarda kesinlikle dikkate alınması gereken unsurların gözden kaçırılmasına neden olabileceğini belirtmektedir.

(i) Yapılmak istenen yatırım amacıyla borç para kullanmamak.

(ii) Çeşitlendirme yaparak hata yapma olasılığını düşürmek

(iii) İlişkili yatırımlardan uzak durmak

(iv) Kısa vadeli nakit ihtiyaçları için elde 3-4 aylık nakit ihtiyacını karşılayacak miktarda nakit bulundurmak.

(v) Yatırım yapılan varlık sınıfını içeren bir endekse yatırım yapmak. Örneğin hisse senedi yatırımı yapıliyorsa bir endeksi baz alan ve baz aldığı endeksin getirisini yatırımcisına yansitmayı amaçlayan borsa yatırım fonlarına yatırım yapılabilir.

Yatırım kararlarında ve işlemlerinde kendine aşırı güvenin kendini belli etmesi mümkün değildir. Bununla birlikte, eğer olabildiğince yüksek tutarlarda yatırım veya işlem yapılmış ise bu kendine aşırı güvenin bir göstergesidir. Kendine aşırı güven nedeniyle yapılan yatırımlardan kazanç elde edilse bile söz konusu kazanç zaman ağırlıklı olarak elde edilecek kazançtan birkaç puan daha düşük olacaktır ve kişi söz konusu potansiyel daha fazla kazançtan habersiz olarak mutluluğunu yaşamaya devam edecektir (Marotta, 2008).

Baker ve Nofsinger (2002), kendine aşırı güvene karşı duyarlı olan yatırımcıların çok fazla işlem yaptıklarını ve çok fazla risk aldıklarını belirtmiş ve bu olumsuzluğun özellikle vergiye tabi ve çeşitlendirilmiş yatırım hesaplarında daha düşük düzeyde işlem gerçekleştirme yolu ile ortadan kaldırılabileceğini belirtmektedirler. Baker ve Nofsinger (2002) aşağıda sıralanan ilkelerin yatırımcı hatalarına neden olan ortak psikolojik yanlılıkların üstesinden gelinmesine yardımcı olabileceğini belirtmişlerdir: 
(i) Psikolojik yanlılıkları anlamak ve maruz kalmaktan sakınmak: $\mathrm{Bu}$ ilkeyi dile getirmek hayata geçirmekten haliyle daha kolaydır. Çünkü yatırımcıların finansal kararlarını etkileyen psikolojik alışkanlıklarının farkında olmaları kolay değildir. Bununla birlikte bireylerin psikolojik karakterleri yatırım davranışları üzerinde önemli bir rol oynar. $\mathrm{Bu}$ nedenle yatırımcıların yaptıkları hataların üstesinden gelebilmeleri servetlerini azaltma olasılığı bulunan psikolojik önyargıları tanımaktan ve kaçınmaktan başlar.

(ii) Yatırım hedeflerinin ve kisitların belirlenmesi: Yatırımcılar psikolojik önyargıların etkisini azaltmak amacıyla getiri beklentilerini ve riske karşı toleranslarını dikkate alarak gerçekçi yatırım hedefleri belirleyebilir. Yine likidite, yatırımın vadesi ve vergiler gibi kısıtları da dikkate almak zorundadırlar. Net bir şekilde belirlenmiş gerçekçi hedefler yatırımcıların çok fazla risk almaktan korunmalarına yardımcı olacaktır.

(iii) Kantitafif yatırım kriterleri belirlemek: Bir dizi kantitatif yatırım kriterlerinin belirlenmesi yatırımcıların duygularına, söylentilere, hikayelere v.b. psikolojik faktörlere yatırım yapmalarının önüne geçecektir. Devamında ise yatırım hedeflerine ulaşmalarına yardım edecektir. Örneğin bir firmanın hisse senedi alınmadan önce yatırımcılar firmanın karakteristik özelliklerini belirledikleri kriterler ile karşılaştırabilirler.

(iv) Yatırımları çeşitlendirmek: Çok sayıda finansal varlık sinıfi arasından (hisse senedi, bono, para piyasası fonları, gayrimenkul) seçilmiş yatırım araçları ile portföy çeşitlendirmesi yapmak getirilerin düzenli ve sabit bir şekilde gerçekleşme olasılığını arttıracak ve riski düşürecektir. Doğru bir çeşitlendirme, yatırımcıları trajik kayıplardan koruyacak ve psikolojik önyargıların olumsuz etkilerine karşı bir kalkan görevi görecektir. Burada varlık sınıfları ve portföyde yer verilecek varlıkların ağırlıkları önemli hale gelmektedir. Bu bağlamda Baker ve Nofsinger (2002), Brinson, Singer ve Beeboer (1991), Ibbotson ve Kaplan (2000) tarafından yapılan çalışmalara atıf yaparak yatırım getirilerinin \%90 oranında uzun vadeli finansal varlıklara dağıtılması sonucu elde edildiğini belirtmektedirler. Portföye eklenecek doğru varlıklar ile çeşitlendirilmiş bir portföyün performansı piyasa zamanlaması ve hisse senedi seçiminden elde edilecek getiriden daha fazla olacaktır. Bununla birlikte daha önce de değinildiği gibi kendine aşırı güven gibi psikolojik faktörlerin olumsuz etkisine maruz kalma düzeylerini düşürmek isteyen yatırımcılar fonlarının bir kısmını endeks yatırım fonlarına yönlendirebilirler.

(v) Gözden geçirme ve yenileme: Yatırımcılar periyodik olarak yatırımlarını incelemeli ve takip etmelidir. Örneğin bir yatırımcı portföyünü yılda en az bir defa kontrol etmeli ve belirlediği yatırım hedefleri ile karşılaştırmalıdır. Eğer her bir varlık sınıfı için istenen ağırlıklardan çok fazla sapma varsa yatırımcı portföyde yer alan varlıkların ağırlıklarını isteği doğrultusunda yeniden ayarlayabilir. Bu şekilde bir girişimde bulunmak yatırımcının yatırım portföyü üzerinde kontrol kazanmasına ve çeşitli psikolojik önyargıların üstesinden gelmesine yardımcı olacaktır.

\section{Sonuç ve Değerlendirme}

Medeniyetlerin ve ekonomik sistemlerin en önemli unsuru olan birey, belirsizlik içeren karar durumları ile karşı karşıya kaldığında diğer insanlara nazaran daha fazla bilgi ile donanımlı olduğuna ve gerçekte olduğundan daha yetenekli olduğuna inanma eğilimi göstermektedir. Kendine aşırı güven en basit anlamıla bireylerin sezgilerine dayanarak yaptıkları akıl yürütme ve karar verme davranışları ile bilişsel yeteneklerine gerçekçi olmayan güvenlerini ifade etmektedir. Kendine aşırı güven önyargısının varlığı davranışsal finans ve bilişsel psikoloji literatürlerinde yer alan çeşitli ölçüm yöntemlerinin kullanıldığı çalışmalarla geniş bir toplum yelpazesini kapsayacak şekilde ortaya konmuştur.

Davranışsal finans literatürünün büyük bir bölümü kendine aşırı güven üzerine yapılan çalışmaların sonuçlarını içermektedir. Kendine aşırı güven kavramı, bilişsel psikolojik araştırmaların kanıtlarından biridir (Michailova, 2010).

İnsanlar kendilerine aşırı güvendikleri için risk alırlar. Kendine aşırı güven sahip olunan bilgiye duyulan aşırı güven nedeniyle yeterince araştırma ihtiyacı duyulmadan kısa yollar kullanılarak karar verilmesini içerir. Örneğin bir paragliding sporcusunun sadece kendi uçuş kabiliyetine güvenmesi ve bu nedenle hem paraşütün durumunu hem de hava durumunu dikkate alma gereği duymaması veya bir yüzücünün yüzme yeteneğine güvenmesi nedeniyle havanın ve denizin durumunu araştırmayı gereksiz çaba olarak görmesi risk unsurunu ortaya çıkartır. Aynı şekilde bir yatırımcının sadece kendi edindiği bilgilere, yatırım yapma yeteneğine veya tekniğine olan güveni ile hareket etmesi yatırım kararlarını etkileyen diğer birçok unsurun dikkate alınmasının önüne geçecektir. Sonuç olarak hatalı yatırım kararı beraberinde finansal anlamda kayıp getirecektir.

Ekonomi ve finans araştırmalarında, deneklerin kendine aşırı güven düzeyinin ölçülmesine yönelik geleneksel bir yöntem yoktur. Bu amaçla, çalışmanın niteliğine ve amacına göre değişen çeşitli araçlar, testler veya ölçekler kullanılır. Ancak bunlardan hiçbirinin tam anlamıyla tatmin edici sonuçlar ortaya koyduğu iddia edilememektedir.

$\mathrm{Bu}$ çalışmada davranışsal finans literatüründe yer alan çalışmalardan hareketle kendine aşırı güven ve ölçülme yöntemleri üzerinde durulmuştur. Sonrasında ise kendine aşırı güvenden sakınma noktasında literatürde yer alan çalışmaların bulguları ve tespitleri özetlenmiştir. Çalışma sonucunda kendine aşırı güveni ölçmek amacıyla kullanılan yöntemlerin temel olarak 3 grup altında toplandığ görülmüştür. Bunlar güven aralıklı anket yöntemi, yöneticilerin kişisel yatırımlarını baz alan yöntemler ve yöneticilerin basındaki profillerinden hareketle kendine aşırı güveni ölçen yöntemlerdir. Kendine aşırı güven, finansal piyasa katılımcılarından biri olan yatırımcıların yatırım davranışlarının incelenmesi bağlamında ele alındığında anket veya kalibrasyona dayanan güven aralıklı anket yoğun olarak kullanıldığı gözlenmiştir. Aynı zamanda kendine aşırı güvenin piyasalarda aşırı işlem hacimlerine neden olduğu ve buna benzer agresif yatırım davranışlarını tetiklediği belirtilmektedir. Kendine aşırı güvenin büyük ölçekli firma 
yöneticilerinin (CEO) aldıkları finansal kararlar bağlamında ölçülmesi gerektiği durumlarda ise opsiyon kullanım davranışlarına dayanan ölçeklerin ve yöneticilerin basın yayın kuruluşlarındaki profillerinin dikkate alındığı görülmüștür. Bununla birlikte farklı çalışmalarda farklı ölçme yöntemlerinin de denendiği görülmüştür.

Kendine aşırı güven hem psikoloji literatüründe hem de davranışsal finans literatüründe oldukça dikkat çeken ve ilgi gören bir davranışsal önyargı çeşididir. $\mathrm{Bu}$ nedenle söz konusu ilginin devam edeceği ve ölçme yöntemlerinin zamanla yeknesak hale geleceği öngörülmektedir. Bu da kendine aşırı güvenin finansal kararlar üzerindeki etkisini konu alan çalışmaların özüne daha fazla zaman ayrılmasını, daha faydalı ve anlamlı sonuçların ortaya konulmasını beraberinde getirecektir.

\section{Kaynakça}

Adam, T. R., Fernando, C. S., \& Golubeva, E. (2015). Managerial overconfidence and corporate risk management. Journal of Banking \& Finance, 60, 195208.

Adams, J. K., \& Adams, P. A. (1961). Realism of confidence judgments. Psychological review, 68(1), 33.

Alpert, M., \& Raiffa, H. (1982). Judgement under Uncertainty: Heuristics and Biases.

Arnott, D. (1998). A taxonomy of decision biases. Monash University, School of Information Management and Systems, Caulfield.

Ataullah, A., Vivian, A., \& Xu, B. (2017). Time-varying managerial overconfidence and corporate debt maturity structure. The European Journal of Finance, 1-31.

Aypay, A. (2008). Gerçekçi Olmayan İyimserlik Kuramı, TSA, 12(1). (Erişim: 11/10/2014) http://www.tsadergisi.org/tsadergi/arsiv/Nisan2008/2.pd f

Baker, H. K., \& Nofsinger, J. R. (2002). Psychological biases of investors. Financial services review, 11(2), 97.

Baker, H. K., \& Nofsinger, J. R. (Eds.). (2010). Behavioral finance: investors, corporations, and markets (Vol. 6). John Wiley \& Sons.

Barber, B. M., \& Odean, T. (2001). Boys will be boys: Gender, overconfidence, and common stock investment. The quarterly journal of economics, 116(1), 261-292.

Barros, L. A. B. D. C., \& Da Silveira, A. D. M. (2007). Overconfidence, managerial optimism and the determinants of capital structure. https://dx.doi.org/10.2139/ssrn.953273

Bazerman, M. (1994). Judgment in Managerial Decision Making. New York: Wiley

Ben-David, I., Graham, J. R., \& Harvey, C. R. (2007). Managerial overconfidence and corporate policies (No. w13711). National Bureau of Economic Research. http://www.nber.org/papers/w13711.pdf

Ben-David, I., Graham, J. R., \& Harvey, C. R. (2013). Managerial Miscalibration. The Quarterly journal of economics, 128(4), 1547-1584.
Bengtsson, C., Persson, M., \& Willenhag, P. (2005). Gender and overconfidence. Economics letters, 86(2), 199-203.

Benos, A. V. (1998). Aggressiveness and survival of overconfident traders. Journal of Financial Markets, 1(3), 353-383.

Biais, B., Hilton, D., Mazurier, K., \& Pouget, S. (2005). Judgemental overconfidence, self-monitoring, and trading performance in an experimental financial market. The Review of economic studies, 72(2), 287-312.

Bierman, H., \& Smidt, S. Jr. (1970), Yatırım Projelerinin İktisadi Analizi ve Finansmanı. Var, T. (çev.). İstanbul: Güzel İstanbul Matbaası.

Billett, M. T., \& Qian, Y. (2008). Are overconfident CEOs born or made? Evidence of self-attribution bias from frequent acquirers. Management Science, 54(6), 1037 1051 .

Brenner, L. A., Koehler, D. J., Liberman, V., \& Tversky, A. (1996). Overconfidence in probability and Frekans (S1klık) judgments: A critical examination. Organizational Behavior and Human Decision Processes, 65(3), 212-219.

Brinson, G.P., Singer, B. D., \& Beebower, G. L (19 91) Determinants of Portfolio Performance II, An Update, Financial Analysts Journal ,47(3), 40-48

Burnside, C., Han, B., Hirshleifer, D., \& Wang, T. Y. (2011). Investor overconfidence and the forward premium puzzle. The Review of Economic Studies, 78(2), 523-558.

Caballé, J., \& Sákovics, J. (2003). Speculating against an overconfident market. Journal of Financial Markets, 6(2), 199-225.

Cambridge, R. M., \& Shreckengost, R. C. (1978). Are You Sure?: The Subjective Probability Assessment Test. Information Science Center, Office of Training, Central Intelligence Agency.

Camerer, C., \& Lovallo, D. (1999). Overconfidence and excess entry: An experimental approach. The American Economic Review, 89(1), 306-318.

Campbell, T. C., Gallmeyer, M., Johnson, S. A., Rutherford, J., \& Stanley, B. W. (2011). CEO optimism and forced turnover. Journal of Financial Economics, 101(3), 695712 .

Campbell, W. K., Goodie, A. S., \& Foster, J. D. (2004). Narcissism, confidence, and risk attitude. Journal of behavioral decision making, 17(4), 297-311.

Chen, G., Crossland, C., \& Luo, S. (2015). Making the same mistake all over again: CEO overconfidence and corporate resistance to corrective feedback. Strategic Management Journal, 36(10), 1513-1535.

Cheng, P. Y. (2007). The trader interaction effect on the impact of overconfidence on trading performance: An empirical study. The Journal of Behavioral Finance, $8(2), 59-69$.

Choi, D., \& Lou, D. (2010, December). A test of the selfserving attribution bias: evidence from mutual funds. In Fourth Singapore International Conference on Finance. 
Conger, R. F., \& Wolstein, C. R. (2004). Managing overconfidence in pricing. Emphasis, (2), 10-13.

Cronqvist, H., Makhija, A. K., \& Yonker, S. E. (2012). Behavioral consistency in corporate finance: CEO personal and corporate leverage. Journal of financial economics, 103(1), 20-40.

Cross, K. P. (1977). Not can, but will college teaching be improved?. New Directions for Higher Education, (17), $1-15$.

Daniel, K. D., Hirshleifer, D. A., \& Subrahmanyam, A. (1998). A theory of overconfidence, self-attribution, and security market under-and over-reactions. J. Finance, (53), 1839-1885.

De Bondt, W. F., \& Thaler, R. H. (1995). Financial decisionmaking in markets and firms: A behavioral perspective. Handbooks in operations research and management science, 9, 385-410.

Diedrichsen, J., \& Shadmehr, R. (2005). Detecting and adjusting for artifacts in fMRI time series data. Neuroimage, 27(3), 624-634.

Dobelli, R. (2013). Hatasız düşünme sanatı: yapmamanız gereken 52 düşünce hatası. (çev. ARDA). Doğuş Yayın Grubu.

Dunlosky, J., \& Metcalfe, J. (2009). Metacognition. London: Sage Publications

Eshraghi, A. (2011). How does Mutual Fund Manager Overconfidence Impact Mutual Fund Investment Performance?. (Accessed on: 12/9/2015), https://www.cass.city.ac.uk/_data/assets/pdf_file/0005/ 79466/Eshraghi.pdf

Fairchild, R. (2010). Behavioural corporate finance: existing research and future directions. International Journal of Behavioural Accounting and Finance, 1(4), 277-293.

Fellner, G., \& Krügel, S. (2012). Judgmental overconfidence: Three measures, one bias?. Journal of Economic Psychology, 33(1), 142-154.

Fischhoff, B., Slovic, P., \& Lichtenstein, S. (1977). Knowing with certainty: The appropriateness of extreme confidence. Journal of Experimental Psychology: Human perception and performance, 3(4), 552.

Fitzsimmons, J. R., \& Douglas, E. J. (2005). The impact of overconfidence on entrepreneurial intentions. In AGSE Entrepreneurship Exchange, February, Auckland, N.Z. (Accessed on: 12/9/2015), http://eprints.qut.edu.au/6490.

Forbes, D. P. (2005). Are some entrepreneurs more overconfident than others?. Journal of business venturing, 20(5), 623-640.

Galasso, A., \& Simcoe, T. S. (2011). CEO overconfidence and innovation. Management Science, 57(8), 1469-1484.

Gerva1s, S., Heaton, J. B., \& Odean, T. (2003). Overconfidence, investment policy, and executive stock options. Rodney L. White Center for Financial Research Working Paper, (15-02).
Gervais, S., Heaton, J. B., \& Odean, T. (2011). Overconfidence, compensation contracts, and capital budgeting. The Journal of Finance, 66(5), 1735-1777.

Gervais, S., Heaton, J. B., \& Odean, T. (2002). The positive role of overconfidence and optimism in investment policy. Rodney L White Center for Financial ResearchWorking Papers-. (Accessed on: 22/09/2014), http://citeseerx.ist.psu.edu/viewdoc/download?doi=10.1. 1.195.7755\&rep=rep $1 \&$ type $=$ pdf

Gigerenzer, G., Hoffrage, U., \& Kleinbölting, H. (1991). Probabilistic mental models: a Brunswikian theory of confidence. Psychological review, 98(4), 506.

Glaser, M., \& Weber, M. (2007). Overconfidence and trading volume. The Geneva Risk and Insurance Review, 32(1), 1-36.

Gort, C. (2009). Overconfidence and active management: An empirical study across Swiss pension plans. The Journal of Behavioral Finance, 10(2), 69-80.

Hackbarth, D. (2002, December). Managerial optimism, overconfidence, and capital structure decisions. In: European Finance Association Annual Meeting,(Aug, 2004), Maasticht, The Netherlands.

Hackbarth, D. (2007), Managerial optimism, overconfidence, and capital structure decisions, Working paper.

Hackbarth, D. (2008). Managerial traits and capital structure decisions. Journal of Financial and Quantitative Analysis, 43(04), 843-881.

Hazard, T. H., \& Peterson, C. R. (1973). Odds versus probabilities for categorical events (Tech. Rep. 73-2). McLean, VA: Decisions and Designs.

Hirshleifer, D., Low, A., \& Teoh, S. H. (2012). Are overconfident CEOs better innovators?. The journal of finance, 67(4), 1457-1498.

Howard, M. E. (1983). The causes of war and other essays. Cambridge, MA: Harvard University Press.

Hribar, P., \& Yang, H. (2016). CEO overconfidence and management forecasting. Contemporary Accounting Research, 33(1), 204-227.

Huisman, R., van der Sar, N. L., \& Zwinkels, R. C. (2012). A new measurement method of investor overconfidence. Economics Letters, 114(1), 69-71.

Hynes, M. E., \& Vanmarcke, E. H. (1976). Reliability of embankment performance predictions. Department of Civil Engineering, Masachusetts Inst. of Technology.

Ibbotson, R. G., \& Kaplan, P. D. (2000). Does asset allocation policy explain 40, 90, or 100 percent of performance?. Financial Analysts Journal, 56(1), 26-33.

Jeong-Ho, K., \& Daecheon, Y. (2018). Managerial Overconfidence, Self-Attribution Bias, and Downwardly Sticky Investment: Evidence from Korea. Emerging Markets Finance \& Trade, 54(1), 144-161. doi:10.1080/1540496X.2017.1398643 
Johnson, D. D. P. (2004). Overconfidence and war: The havoc and glory of positive illusions. Cambridge, MA: Harvard University Press

Jonsson, A. C., \& Allwood, C. M. (2003). Stability and variability in the realism of confidence judgments over time, content domain, and gender. Personality and Individual Farks, 34(4), 559-574.

Kahyaoğlu, M. T. (2012). Demografik ve sosyo-ekonomik faktörlerin aşırı güven bilişsel önyargısı üzerindeki etkisi: İMKB bireysel hisse senedi yatırımc1ları üzerine bir analiz. Finans Politik Ve Ekonomik Yorumlar, 49(563), 73.

Keh, H. T., Foo, M. D., \& Lim, B. C. (2002). Opportunity evaluation under risky conditions: The cognitive processes of entrepreneurs. Entrepreneurship theory and practice, 27(2), 125-148.

Keren, G. (1997). On the calibration of probability judgments: Some critical comments and alternative perspectives. Journal of Behavioral Decision Making, 10(3), 269-278.

Klauss, P. C. (2006). Capital Investment Decisions with Managerial Overconfidence and Regret Aversion. $\mathrm{PhD}$ Thesis. University of Bath School of Management.

Klayman, J., Soll, J., Gonzalez - Vallejo, C., \& Barlas, S. (1999). Overconfidence: It depends on how, what, and whom you ask. Organizational Behavior and Human Decision Processes, 79, 216 - 247.

Korıat, A., Lichtenstein, S., \& Fischhoff, B. (1980). Reasons for confidence. Journal of Experimental Psychology: Human learning and memory, 6(2), 107.

Korkmaz, T., \& Çelik, E. İ. (2007). Davranışsal finans modellerinden aşırı güven hipotezinin geçerliliği: IMKB'de bir uygulama. Íktisat İsletme ve Finans, 22(261), 137-154.

Kufepaksi, M. (2007). The Effect of Overconfident Behavior on the Process of Forming and Correcting The Values of The Security in Market Experiment: The Implication of Self Deceptive Behavior in a Security Market. Dissertation. unpublished.

Küçüksille, E., Özmutaf, N. M., \& Mizrahi, R. (2016). The Overconfidence Perceptions of Individual Investors in Concept of Socio Demographic Factors: Evidence From Izmir. Suleyman Demirel University Journal Of Faculty Of Economics \& Administrative Sciences, 21(3), 10331041.

Kyle, A. S., \& Wang, F. A. (1997). Speculation duopoly with agreement to disagree: Can overconfidence survive the market test?. The Journal of Finance, 52(5), 2073-2090.

Lai, L. (2011). Behavioral biases in corporate financial decision making. Bachelor Thesis. Tilburg University.

Langer, E. J. (1975). The illusion of control. Journal of personality and social psychology, 32(2), 311.

Latumahina, D. (2010), Danger of Overconfidence, (Accessed on 06/12/2017), https://www.lifeoptimizer.org/2010/05/03/danger-ofoverconfidence/
Lichtenstein, S., Fischhoff, B., \& Phillips, L.D. (1982). Calibration of subjective probabilities: The state of the art up to 1980. In: D. Kahneman, P. Slovic, \& A. Tversky (Eds.), Judgment under uncertainty: Heuristics and biases (pp. 306-334). New York: Cambridge University Press.

Lichtenstein, S., \& Fischhoff, B. (1977). Do those who know more also know more about how much they know? Organizational Behavior and Human Performance, 20(2), 159-183.

Liu, Y., \& Taffler, R. (2008, August). CEO overconfidence in M\&A decision making and its impact on firm performance. In: Annual Conference of the French Finance Association (pp. 20-22).

Malmendier, U., \& Tate, G. (2002). Does CEO overconfidence drive corporate acquisitions?. Working paper, Harvard University.

Malmendier, U., \& Tate, G. (2005a). CEO overconfidence and corporate investment. The journal of finance, 60(6), 2661-2700.

Malmendier, U., \& Tate, G. (2005b). Does overconfidence affect corporate investment? CEO overconfidence measures revisited. European Financial Management, 11(5), 649-659.

Malmendier, U., \& Tate, G. (2008). Who makes acquisitions? CEO overconfidence and the market's reaction. Journal of financial Economics, 89(1), 20-43.

Malmendier, U., Tate, G., \& Yan, J. (2011). Overconfidence and early-life experiences: the effect of managerial traits on corporate financial policies. The Journal of finance, 66(5), 1687-1733.

Marotta, D. J. (2008), Behavioral Finance: Overconfidence. (Accessed on: 10//12/2017), http://www.marottaonmoney.com/behavioral-financeoverconfidence/

Mcclelland, A., \& Bolger, F. (1994). The calibration of subjective probabilities: Theories and models 19801993. In: George Wright and Peter Ayton (eds.), Subjective Probability. Wiley, Chichester.

Menkhoff, L., Schmidt, U., \& Brozynski, T. (2006). The impact of experience on risk taking, overconfidence, and herding of fund managers: Complementary survey evidence. European Economic Review, 50(7), 17531766.

Michailova, J. (2010). Overconfidence and bubbles in experimental asset markets. (Accessed on 10/02/2015) https://mpra.ub.unimuenchen.de/30579/1/MPRA_paper_30579.pdf

Molenberghs, P., Trautwein, F. M., Böckler, A., Singer, T., $\&$ Kanske, P. (2016). Neural correlates of metacognitive ability and of feeling confident: a large-scale fMRI study. Social cognitive and affective neuroscience, 11(12), 1942-1951.

Moore, D. A., \& Healy, P. J. (2008). The trouble with overconfidence. Psychological review, 115(2), 502. 
Mullainathan, S., \& Thaler, R. H. (2000). Behavioral economics (No. w7948). National Bureau of Economic Research.

Murphy, A. H. (1973). A new vector partition of the probability score. Journal of Applied Meteorology, 12(4), 595-600.

Neale, M. A., \& Bazerman, M. H. (1991). Cognition and rationality in negotiation. Free Press.

Odean, T. (1998). Volume, volatility, price, and profit when all traders are above average. The Journal of Finance, 53(6), 1887-1934.

Oskamp, S. (1965). Overconfidence in case-study judgments. Journal of consulting psychology, 29(3), 261.

Palomino, F., \& Sadrieh, A. (2011). Overconfidence and delegated portfolio management. Journal of Financial Intermediation, 20(2), 159-177.

Parker, A. M., \& Fischhoff, B. (2005). Decision-making competence: External validation through an individual differences approach. Journal of Behavioral Decision Making, 18(1), 1-27.

Parkinson, M. (1980). The extreme value method for estimating the variance of the rate of return. Journal of business, 61-65.

Peng, L., \& Xiong, W. (2006). Investor attention, overconfidence and category learning. Journal of Financial Economics, 80(3), 563-602.

Pikulina, E. S., Renneboog, L. D. R., Ter Horst, J. R., \& Tobler, P. N. (2013). Overconfidence, Effort, and Investment (Replaced by CentER DP 2014-039). CentER Discussion Paper, 2013.

Plous, S. (1993). The psychology of judgment and decision making. Mcgraw-Hill Book Company.

Pulford, D. B. (1996), Overconfidence in Human Judgment. $\mathrm{PhD}$ thesis. University of Leicester.

Roll, R. (1986). The hubris hypothesis of corporate takeovers. Journal of business, 197-216.

Russo, J. E., \& Schoemaker, P. J. (1992). Managing overconfidence. Sloan Management Review, 33(2), 7-17.

Schaefer, P. S., Williams, C. C., Goodie, A. S., \& Campbell, W. K. (2004). Overconfidence and the big five. Journal of Research in Personality, 38(5), 473-480.

Scheinkman, J. A., \& Xiong, W. (2003). Overconfidence and speculative bubbles. Journal of political Economy, 111(6), 1183-1220.

Sen, R., \& Tumarkin, R. (2015). Stocking up: Executive optimism, option exercise, and share retention. Journal of Financial Economics, 118(2), 399-430.

Shao, X., \& Wang, L. (2013). Manager's Irrational Behavior in Corporate Capital Investment DecisionMaking. International Journal of Economics, Finance and Management, 3(4), 183-193.

Shefrin, H. (2002). Behavioral decision making, forecasting, game theory, and role-play. International journal of forecasting, 18(3), 375-382.
Shiller, R. J. (1999). Human behavior and the efficiency of the financial system. Handbook of macroeconomics, 1 , 1305-1340.

Shiller, R. J. (2000). Irrational Exuberance. Princeton, N.J.: Princeton Univ. Press.

Simon, M., \& Houghton, S. M. (2003). The relationship between overconfidence and the introduction of risky products: Evidence from a field study. Academy of Management Journal, 46(2), 139-149.

Simon, M., Houghton, S. M., \& Aquino, K. (2000). Cognitive biases, risk perception, and venture formation: How individuals decide to start companies. Journal of business venturing, 15(2), 113-134.

Skala, D. (2008). Overconfidence in Psychology and Finance-an Interdisciplinary Literature Review (No. 26386). Germany: University Library of Munich.

Slovic, P., Fischhoff, B., \& Lichtenstein, S. (1977). Behavioral decision theory. Annual review of psychology, 28(1), 1-39.

Soll, J. B. (1996). Determinants of overconfidence and miscalibration: The roles of random error and ecological structure. Organizational Behavior and Human Decision Processes, 65(2), 117-137.

Statman, M., Thorley, S., \& Vorkink, K. (2006). Investor overconfidence and trading volume. The Review of Financial Studies, 19(4), 1531-1565.

Stechyshyna, N. (2017). Manager's Overconfidence and Risk Taking Aptitudes and The Cross Industry Acquisitions. (Accessed on 05/12/2017), http://arno.uvt.nl/show.cgi?fid=129513

Sutherland, S. (2015). The dangers of overconfidence for ISA and SIPP Investors. (Accessed on 05/12/2017), https://www.isaco.co.uk/blog/bid/206265/The-dangersof-overconfidence-for-ISA-and-SIPP-Investors

Svenson, O. (1981). Are we all less risky and more skillful than our fellow drivers?. Acta Psychologica, 47(2), 143148 .

Şahin, S., \& Yılmaz, Ö. (2014). Overconfidence in Finance with Different Domains: An Interdisciplinary Experimental Approach. Cumhuriyet Üniversitesi Íktisadi ve İdari Bilimler Dergisi, 15(1), 253-268.

Taylor, S. E., \& Brown, J. D. (1988). Illusion and well-being: a social psychological perspective on mental health. Psychological bulletin, 103(2), 193.

Tekin, B. (2015). Firmaların Finansal Kararları Üzerinde Davranışsal Önyargıların Etkisi. Doktora Tezi. Sakarya: Sakarya Üniversitesi.

Tekin, B. (2016). Firmaların Finansman Kararları: Davranışsal Perspektif. Akademik Araştırmalar ve Çalışmalar Dergisi (AKAD), 8(15), 169-198.

Tomak, S. (2013). The impact of overconfidence on capital structure in Turkey. International Journal of Economics and Financial Issues, 3(2), 512-518.

Trinugroho, I., \& Sembel, R. (2011). Overconfidence and Excessive Trading Behavior: An Experimental Study. 
International Journal of Business and Management, 6(7), 147.

Tversky, A., \& Kahneman, D. (1974). Judgment under uncertainty: Heuristics and biases. science, 185(4157), 1124-1131.

Vermeulen, A. (1996). Declining Androgens with Age: An Overview. In: Vermeulen, A., \& Oddens, B. J. (Eds.), Androgens and the Aging Male, 3-14

Von Holstein, C. A. S. S. (1972). Probabilistic forecasting: An experiment related to the stock market. Organizational Behavior and Human Performance, 8(1), 139-158.

Wagenaar, W. A., \& Keren, G. B. (1986). Does the expert know? The reliability of predictions and confidence ratings of experts. In: Intelligent decision support in process environments (pp. 87-103). Springer Berlin Heidelberg.

Wang, F. A. (1998). Strategic trading, asymmetric information and heterogeneous prior beliefs. Journal of Financial Markets, 1(3-4), 321-352.

Wang, F. A. (2001). Overconfidence, investor sentiment, and evolution. Journal of Financial Intermediation, 10(2), 138-170.

Ward, W. C., \& Jenkins, H. M. (1965). The display of information and the judgment of contingency. Canadian Journal of Psychology/Revue canadienne de psychologie, 19(3), 231.

Weinstein, N. D. (1980). Unrealistic optimism about future life events. Journal of personality and social psychology, 39(5), 806.

Weinstein, N. D. (1982). Unrealistic optimism about susceptibility to health problems. Journal of behavioral medicine, 5(4), 441-460.

Xia, T., Wang, Z., \& Li, K. (2014). Financial literacy overconfidence and stock market participation. Social indicators research, 119(3), 1233-1245.

Yates, J. F. (1990). Judgment and decision making. PrenticeHall, Inc.

Yates, J. F., Lee, J. W., Shinotsuka, H., Patalano, A. L., \& Sieck, W. R. (1998). Cross-cultural variations in probability judgment accuracy: Beyond general knowledge overconfidence?. Organizational behavior and human decision processes, 74(2), 89-117.

Ying, H., Xing, L., \& Chao-nan, L. (2005). An empirical research on the general manager overconfidence and investment decision for the listed companies. Chinese Journal of Management Science, 13(5), 142-48. 